\title{
Timing of Medieval Fluvial Aggradation at Bremgarten in the Southern Upper Rhine Graben - a Test for Luminescence Dating
}

\author{
Manfred Frechen, Dietrich Ellwanger, Daniel Rimkus \& Astrid Techmer *)
}

\begin{abstract}
The Holocene flood plain of the River Rhine is a complex dynamic sedimentary system. A series of geochronological results for the Bremgarten section including optically stimulated luminescence (OSL) and radiocarbon dating was determined to improve the understanding of part of the Holocene evolution of the River Rhine. The applied single aliquot regenerative (SAR) protocols and the applied experimental studies to find the best luminescence behaviour leave us with confidence that OSL dating is a suitable method for dating fluvial sediments from large river systems. Insufficient bleaching of the sediments from Bremgarten prior to deposition seems to be not as dramatic as previously thought. OSL and radiocarbon dating results give evidence for a short period of major erosion and re-sedimentation of fluvial sediments from the "Tiefgestade" at the Bremgarten section between 500 and 600 years before present. This time period correlates with the beginning of the Little Ice Age at about AD 1450. Several severe floods occurred in Southern Germany between $\mathrm{AD} 1500$ and 1750; all those floods correlate to the period of the Little Ice Age, including the destruction of the village of Neuenburg AD 1525.
\end{abstract}

[Die zeitliche Stellung einer mittelalterlichen fluvialen Sedimentakkumulation im südlichen Oberrheingraben am Beispiel Bremgarten - ein Test für Lumineszenz-Datierungen]

Kurzfassung: Die holozäne Überflutungsebene des Rheins ist ein komplexes sedimentäres System. Die geochronologischen Untersuchungen mittels Optisch Stimulierter Lumineszenz (OSL) und Radiokohlenstoff-Datierungsmethode verbessern das Verständnis der holozänen Entwicklung des Rheinsystems und ermöglichen quantitative Studien zu Aggradationsphasen von Flüssen. Die angewandten Single-Aliquot-Regenerierung (SAR)-Protokolle und die angewandten experimentellen Untersuchungen zur Absicherung der Messparameter lassen erkennen, dass die OSL-Datierungstechnik eine geeignete Datierungsmethode für fluviatile Sedimente aus großen Flusssystemen ist. Eine unvollständige Bleichung der fluviatilen Sedimente vor der Ablagerung scheint für die Sedimente aus Bremgarten nicht so dramatisch zu sein wie ursprünglich vermutet. OSL- und Radiokohlenstoff-Datierungsergebnisse bestätigen eine kurze Periode starker Erosion und Akkumulation im Bereich des Tiefgestades von Bremgarten zwischen 500 und 600 Jahren vor heute. Dieses Zeitfenster korreliert mit dem Beginn der Kleinen Eiszeit um ca. AD 1450. Mehrere schwere Flussüberschwemmungen geschahen in Süddeutschland zwischen AD 1500 und 1750. Diese Überschwemmungsereignisse korrelieren mit dem Zeitfenster der Kleinen Eiszeit, darunter die Zerstörung von Neuenburg im Jahre 1525.

Keywords: Upper Rhine Graben, river aggradation, OSL chronology, Little Ice Age, Quaternary

* Adresses of authors: M. Frechen, Leibniz Institute for Applied Geophysics, Section S3: Geochronology and Isotope Hydrology, Stilleweg 2, 30655 Hannover, Germany. E-Mail: Manfred.Frechen@liaghannover.de; D. Ellwanger, Regierungspräsidium Freiberg, Landesamt für Geologie, Rohstoffe und Bergbau Baden-Württemberg, Albertstr. 5, 79104 Freiburg, Germany; A. Techmer, Leibniz Institute for Applied Geophysics, Section S3: Geochronology and Isotope Hydrology, Stilleweg 2, 30655 Hannover, Germany; D. Rimkus, Freie Universität Berlin, Geographical Sciences, Physical Geography, Malteserstr. 74-100, Haus H, 12249 Berlin, Germany 


\section{Introduction}

Investigating terrestrial sediment archives of the past is imperative to learning and understanding the future impact of climate and environmental changes. The Medieval climate optimum and the Little Ice Age are two historically recorded periods during which society was considerably influenced by climate and environment change. Fluvial landscapes in modern floodplains and lower terraces are particularly sensitive to climate change. Extreme weather events such as the millenium flood of the year AD 1342 had a catastrophic impact on Man and the society and indeed caused a significant alteration of landscape, such as up to $15 \mathrm{~m}$ deeply incised canyons and reworking of up to $8 \mathrm{~m}$ thick fluvial sediments in southern Germany (Bork 1989). The extent of the fluvial dynamics and the temporal succession of such events are not yet understood in either large or small rivers.

Extensive research has been carried out in the catchment area of the River Rhine on Pliocene and Pleistocene terrace formation (e.g. BoENIGK \& Frechen 2006; Hagedorn \& BoenigK 2008, Westerhoff 2008; and references within) demonstrating the complexity of this major fluvial sediment archive. The large increase in terrigenous sediment supply during the Quaternary is a result of continuous disequilibrium between weathering, erosion, sediment transport and aggradation triggered by climatic perturbations (HINDERER 2001). Increased aggradation in the southern Upper Rhine Graben (URG) postdates the filling up of the Lake Constance (Bodensee) Basin and occurred synchronous with periods of major ice melting (WESSELS 1998). During these highly dynamic periods, including the glacial overdeepening of Alpine valleys, the peri-alpine basins were deeply eroded. Late Glacial and Holocene fluvial aggradation and terrace formation are triggered by climate change and tectonic processes as well as human-induced adjustment of river systems (Schirmer et al. 2005; Bos et al. 2008; ERKENS et al. 2009; LÄMMERMANN-BARTHEL et al. in press). During the Little Ice Age, signifi- cant erosion and aggradation occurred along the Rhine.

Little is known about the timing of the Holocene fluvial activity of the River Rhine in the southern Upper Rhine Graben (URG). Historical data is available for major flood events during Medieval times. Numerical dating of fluvial sediments is problematical, as described in detail for the Middle and Lower Rhine area by Boenigk \& Frechen $(1998,2006)$ and the northern Upper Rhine Graben by ERKENS et al. (2009) and Frechen et al. (2006). During the past 15 years, much attention has been paid on the investigation of the timing of fluvial activity in the Rhine system. Fluvial sediments are particularly suitable for the application of optically stimulated luminescence (OSL) dating techniques (Busschers 2008; JAIN et al. 2003; Wallinga 2002). In this study, OSL dating on fine-sand and radiocarbon dating on wood was carried out on Holocene material from the gravel pit at Bremgarten in the southern part of the Upper Rhine Graben.

The aim of this study is to test the suitability of fluvial sediments for OSL dating and to give a more reliable chronological interpretation for the Medieval fluvial activity in the southern part of the URG. This is part of an ongoing study investigating fluvial sediments from the Rhine system in the frame of the Heidelberg Drilling Project.

\section{Geological setting}

The Upper Rhine Graben is located between the cities of Basel and Mainz. Its extension has a length of about $300 \mathrm{~km}$ and a width of up to $36 \mathrm{~km}$ and about $20 \mathrm{~km}$ in the southern part and in the northern part, respectively. The altitude of the River Rhine decreases from about $280 \mathrm{~m}$ above sea level (asl) in the south near Basel to about $80 \mathrm{~m}$ asl in the north near Mainz. The River Rhine flows in numerous meanders northwards, which were partly regulated in the years between 1817 and 1874 .

The maximum subsidence of the Quaternary is located in the Heidelberg Basin near to the city of Heidelberg. BARTZ (1951, 1967, 1974) 


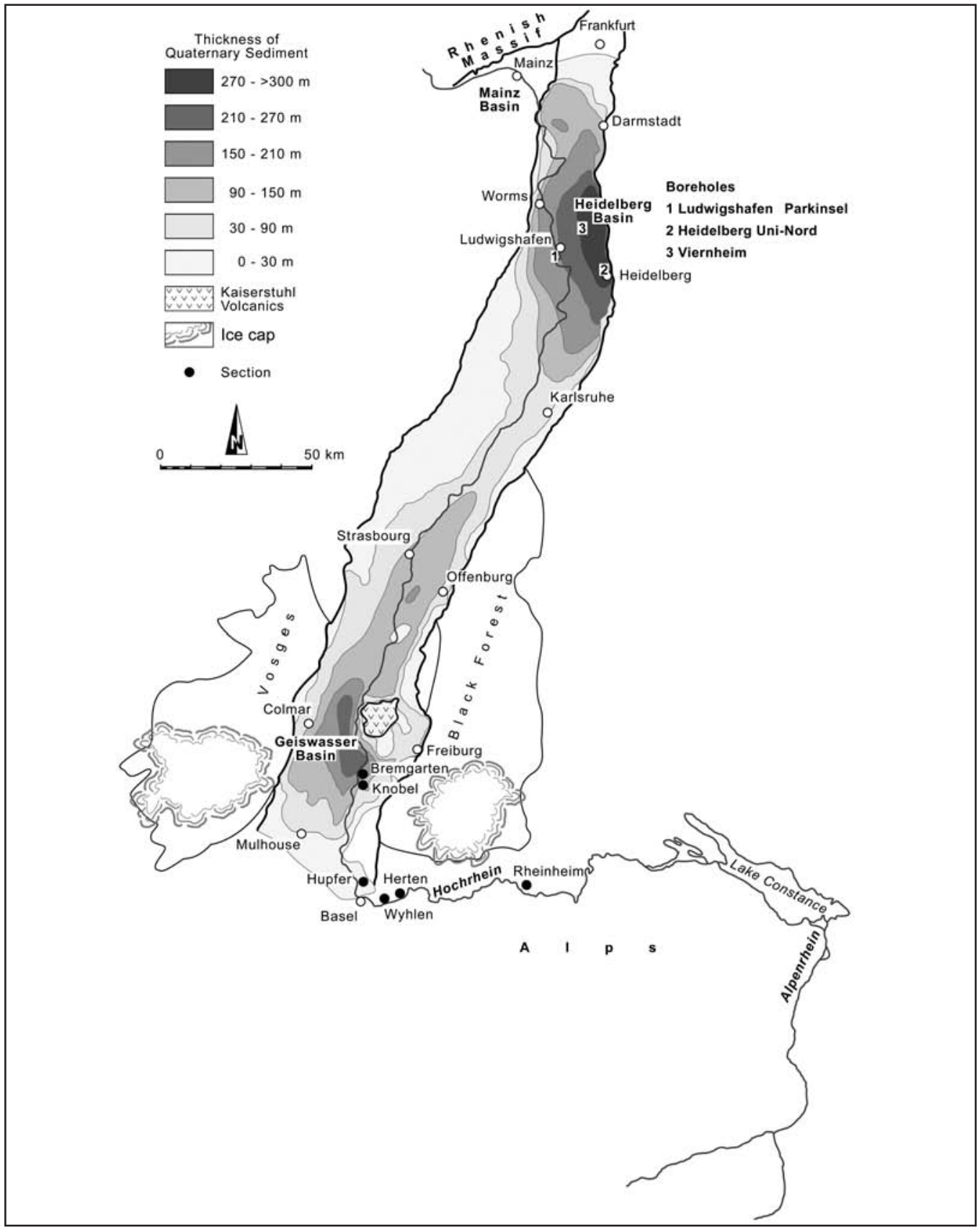

Fig. 1: Map showing the location of the Bremgarten section and the thickness of Quaternary sediments and the position of boreholes of the Heidelberg Drilling Project in the Upper Rhine Graben, modified after HAGEDORN (2004) and BARTZ (1974).

Abb. 1: Geographische Lage des Aufschlusses Bremgarten und der Bohrlokalitäten des Bohrprojektes Heidelberger Becken sowie Mächtigkeit der quartären Sedimente im Oberrheingraben modifiziert nach HaGEDORN (2004) und BARTZ (1974). 
reported a thickness of more than $300 \mathrm{~m}$ for the Quaternary sequence and about $680 \mathrm{~m}$ for the Pliocene record. The Heidelberg Drilling Project including the up to $500 \mathrm{~m}$ long sediment cores from the sections at Heidelberg-UniNord, at Ludwigshafen-Parkinsel (WEIDENFELLER \& KäRCHER 2008) and at Viernheim, is currently aiming to reconstruct in detail the sediment archive of the basin fill (Fig. 1) (Ellwanger et al. 2005). A zone of elevated seismic activity is evidenced by the historical earthquakes of Basel Anno Domini (AD) 1021 and AD 1356. In the southern URG, tectonically active faults have caused offsets of up to $20 \mathrm{~m}$ during the Holocene (HütTNER 1991) resulting in a distinct terrace step east of the river Rhine. The higher level is called "Hochgestade" and the lower part between the step and the river is called "Tiefgestade". The difference in altitude between "Hochgestade" and "Tiefgestade" reaches several metres and has formed by a tectonically active fault propagating parallel to the present river course (BRAM et al. 2005). NIVIÈRE et al. (2008) calculated maximum vertical movements along the faults not exceeding $1.0 \mathrm{~mm} / \mathrm{yr}$ since the Middle Pleistocene. The current activity is concentrated along the westernmost faults. The coordinates of the section under investigation are H5309115 and R3394285 of the GaussKrüger system used in German topographic maps. The gravel pit Bremgarten $\mathrm{GmbH}$ is located about $150 \mathrm{~m}$ east of the river Rhine and situated in the lowermost part of the Lower Terrace termed "Tiefgestade" in the vicinity of the villages Bremgarten and Hartheim. About $7 \mathrm{~m}$ thick sand and gravel successions are exposed including pebbles originating from the Swiss Alps and the Black Forest. The upper part of the sediment succession is coarser than the lower part. A sand lens is covered by not wellsorted gravel about $2 \mathrm{~m}$ thick sand-rich. Up to three horizons can be distinguished and make three deposition events likely (Fig. 2, 3). Wood was collected for radiocarbon dating from the western wall about $3 \mathrm{~m}$ below surface. In 2006, two further trunks were exposed in the south wall and sampled for radiocarbon dating. The two trunks were located at the top of a sand layer which correlates to the base of a fining up cycle. The trunk has a north-south orientation, which is very likely the transport direction in the river at the time of deposition (Fig. 2). The lower part of the tree has still its bark, whereas the upper part of the trunk is bare of bark, most likely owing to erosion by water and sediment immediately after deposition of the trunk.

Sample BRE3 was taken $20 \mathrm{~cm}$ above the trunk and sample BRE4 was taken from about $20 \mathrm{~cm}$ below the trunk for OSL dating. Samples BRE1 and BRE2 were taken from a sand lens intercalated in light-greyish gravel from the eastern quarry wall in 2003 (Fig. 3). A piece of wood was intercalated in the sand lens, as previously described by LÄMMERMANN-BARTHEL et al. (in press) and used for radiocarbon dating.

Massive Alpine sediment supply into the URG is unlikely for Medieval times, as lake Constance again formed as a sediment trap for the River Rhine (WESSELS 1998). In the geological past, massive Alpine sediment supply probably resulted in a lateral movement of the Rhine over the whole southern URG (LÄMMERMANNBARTHEL et al. in press).

\section{Luminescence dating}

Luminescence dating of aeolian and fluvial sediments has proved to be successful where radiocarbon and other dating methods are not applicable (FreCHEN et al. 1997; JAIN et al. 2003; LiAn \& Roberts 2006; RitTENTOUR 2008). Since the late 1980s, luminescence dating of sediments has significantly been improved by the development of more light sensitive techniques such as green or blue optically stimulated luminescence (OSL) or infrared optically stimulated luminescence (IRSL) for monomineralic quartz or feldspar subsamples, respectively (HuNTLEY et al. 1985; HütT et al. 1988). A recent review about the lower and upper dating limit is found in WinTLE (2008).

The basic principle of luminescence dating is solid state dosimetry of ionising radiation (WINTLE 1997; AitKen 1998; Preusser et al. 2008).

The quartz signal saturates at lower doses than the feldspar signal. However, the advantage is often offset by the larger dose rates for the feld- 


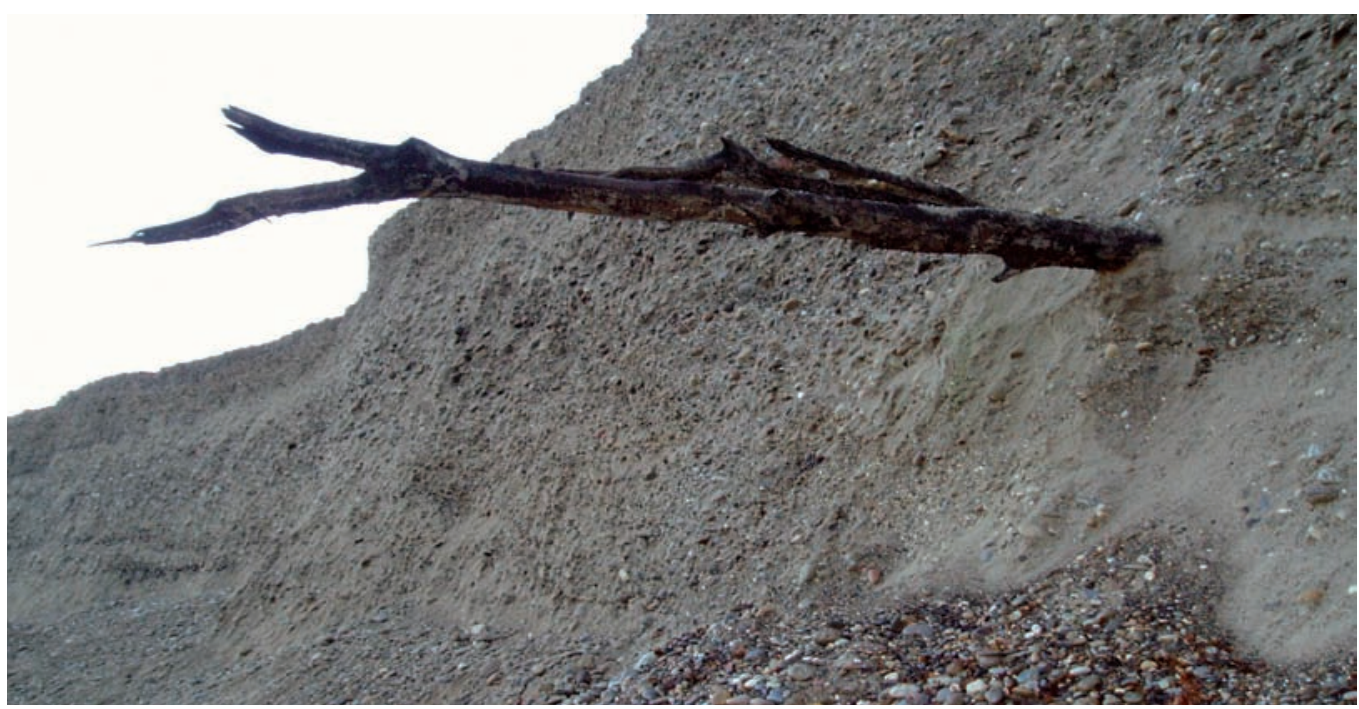

Fig. 2: Picture showing the position of the samples under study. A trunk is intercalated in sandy sediments (sand lense). The trunk was sampled for radiocarbon dating. Two samples were taken from sand about $20 \mathrm{~cm}$ below (LUM1220) and about $20 \mathrm{~cm}$ above (LUM1219) the trunk.

Abb. 2: Foto der Position der Probennahmepunkte im Aufschluss Bremgarten. Ein Baumstamm ist in die sandigen Sedimente zwischen geschaltet (Sandlinse). Das Holz wurde zur Radiokohlenstoff-Datierung beprobt. Jeweils eine Probe wurde $20 \mathrm{~cm}$ unterhalb (LUM1220) und oberhalb (LUM1219) des Baumstammes für OSL-Datierungen entnommen.

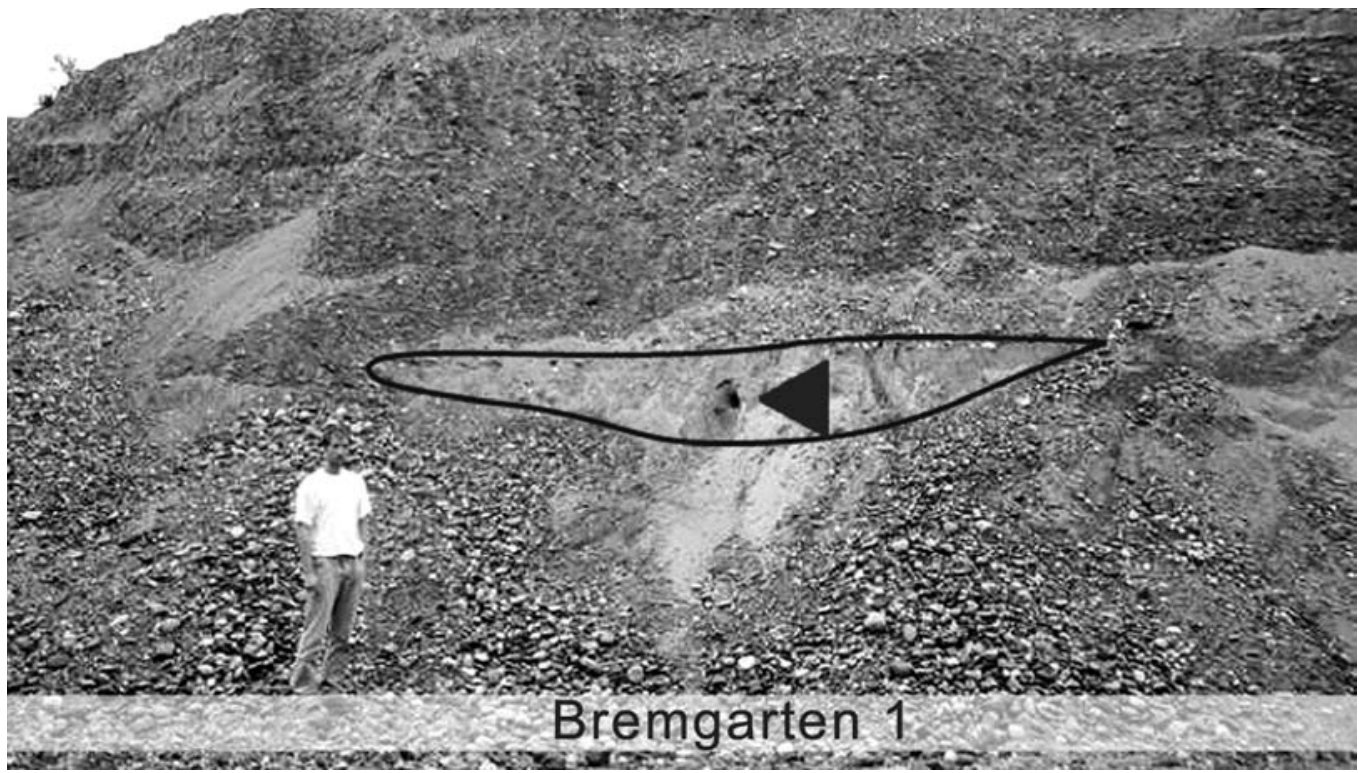

Fig. 3: Picture showing the position of sample BRE1. A second trunk was found $150 \mathrm{~m}$ in the north of the profile under study and sampled for radiocarbon dating.

Abb. 3: Foto mit der Position der Probe BRE1. Ein weiterer Baumstamm wurde etwa $150 \mathrm{~m}$ nördlich dieses Profils für eine Radiokohlenstoff-Datierung entnommen. 


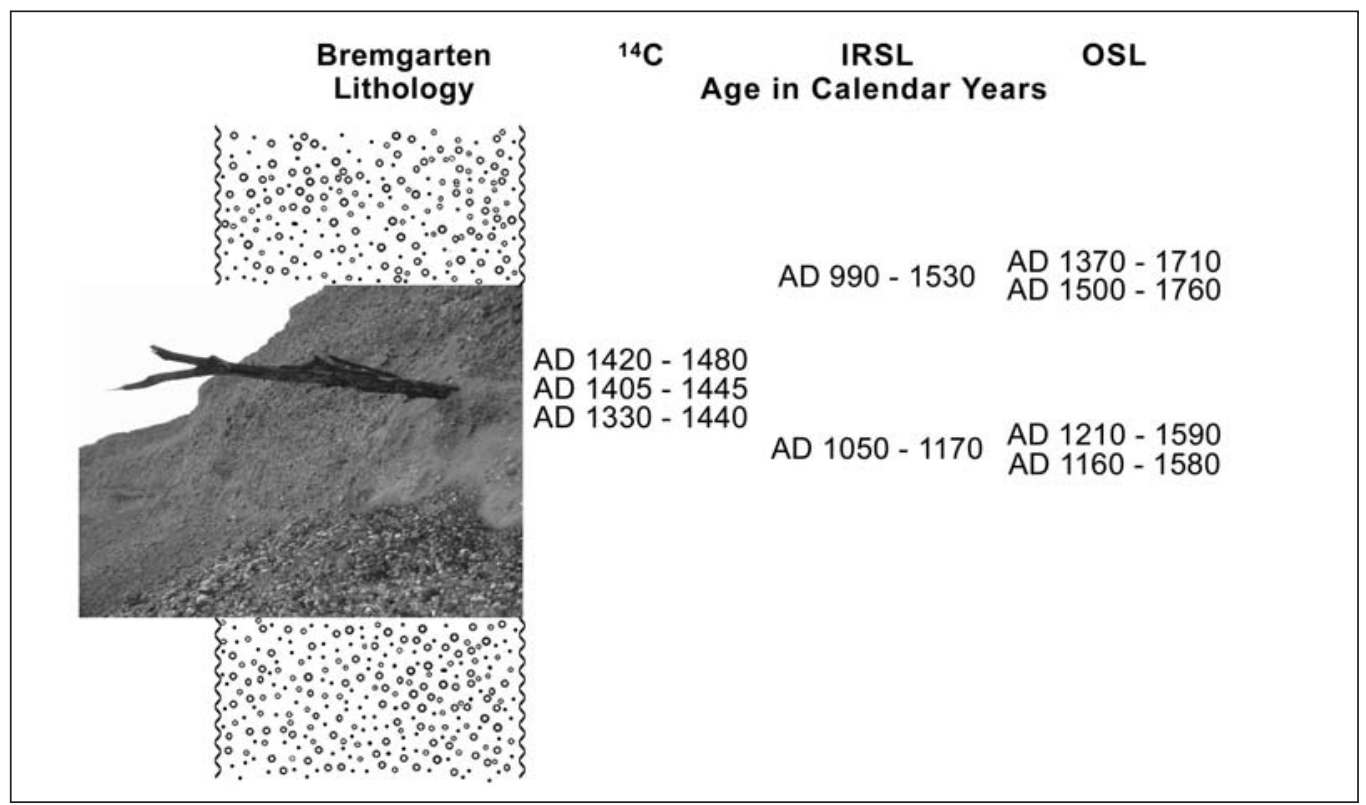

Fig. 4: Idealised sketch of the lithological units and the geological interpretation and position of radiocarbon and luminescence samples.

Abb. 4: Idealisierte Abbildung der Sedimentabfolge in Bremgarten mit geologischer Interpretation und Position der Radiokohlenstoff- und Lumineszenzproben.

spars owing to high potassium content within the feldspar mineral grains and athermal signal instability owing to anomalous fading (WINTLE 1973).

An important assumption of luminescence dating techniques is that the mineral grains were sufficiently long exposed to daylight/sunlight prior to deposition to reset the radiometric clock ("zeroing the luminescence signal"). The level of zeroing depends on the exposure time of the mineral grains to light, the available light intensity and the light spectrum. These parameters are strongly affected by fluvial sedimentary dynamics including water depth, sediment load, turbulence and turbidity, grain-size and transportation distance (RHODES \& Pownall 1994; Frechen 1995; Murray et al. 1995; WALLinga et al. 2000; JAIN et al. 2003). In many fluvial environments the probability of complete zeroing of all sediment grains is low. JAIN et al. (2003), WALlinga (2002) and SingARAYER et al. (2005) pointed out that in contrast to aeolian sediment a distribution of values deter- mined for fluvial deposits usually results in age overestimation, if equivalent doses are measured for samples containing a large number of grains. Fuchs et al. (2005) reported that quartz based equivalent dose $\left(\mathrm{D}_{\mathrm{e}}\right)$ values yielded distinctly lower results than feldspar based $\mathrm{D}_{\mathrm{e}}$ values for flood sediments giving evidence for better bleaching of quartz minerals extracted from the sediment. However, in large river systems the zeroing has been found to be more complete or nearly complete owing to the very likely multiple recycling of sediment during repeated phases of deposition and erosion (WALlinga 2002). Most bleaching does occur when the grains are close to the water surface where the light intensity is greater and the light spectrum is more complete. Sediment from overbank deposits and scour pools are more likely to be suitable for luminescence dating. Samples taken from sediment of high-energy depositional environments like mass flow deposits or sediments from kames, are not suitable for luminescence dating (HüTT \& JungNER 1992). Partial bleaching of sediments 
is also attributed to flashy seasonal river flow (floods) associated with high-amplitude precipitation causing input from bank erosion (JAIN et al. 2003). The existence of scatter in equivalent dose determinations is an indication for incomplete zeroing of the OSL signal. Grain-to-grain variations do produce scatter in single aliquot equivalent dose determinations (LAMOTHE et al. 1994; Murray \& Roberts 1997; Olley et al. 1999). The detection of partial bleaching was previously investigated by using small single aliquots or single-grain methodology (FucHS \& Wagner 2003; Singarayer et al. 2005; Preusser et al. 2007) and different statistical approaches
(LePper et al. 2000; Bailey \& Arnold 2006; ERKENS et al. 2009). Following these studies, it appears to be mandatory to investigate a large number of single grains per sample from fluvial environments.

The first fluvial sediments from Germany, which were investigated by a dating approach combining IRSL, OSL and thermoluminescence (TL), were taken from sand layers of the Lower Terrace from the River Emscher (FRECHEN 1995). TL dating results showed large uncertainties most likely owing to incomplete bleaching prior to deposition; IRSL dating of potassium-rich feldspars showed a better

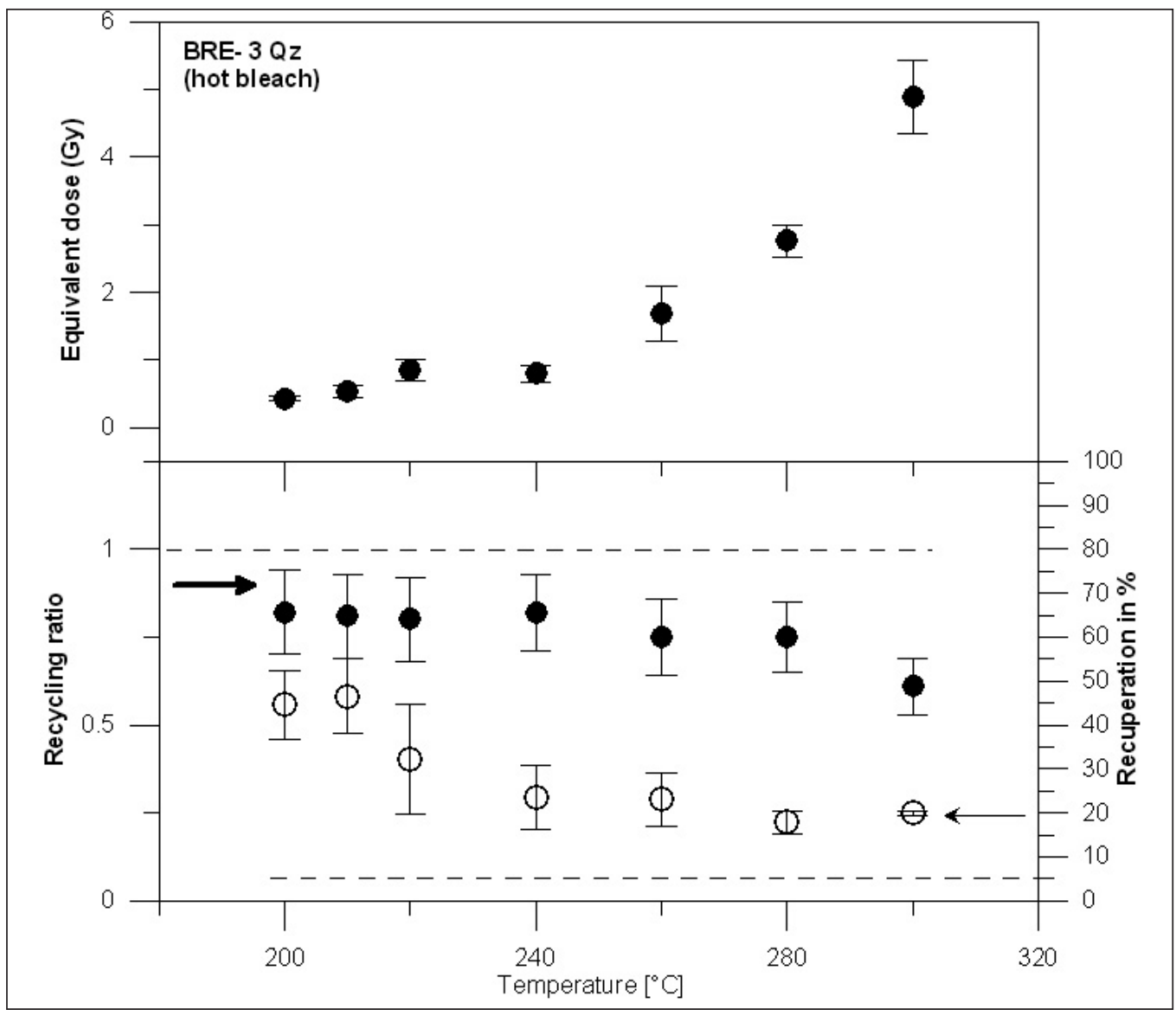

Fig. 5: Preheat plateau, recycling ratio and recuperation for sample BRE3 using quartz extracts and the hot bleach procedure.

Abb. 5: „Preheat plateau”, „Recycling Ratio” und „Recuperation” für Quarze der Probe BRE3 unter Anwendung des „Hot Bleach”-Verfahrens. 
agreement with the geological age estimates. FreCHEN (1995) suggested to investigate 100$200 \mu \mathrm{m}$ potassium-rich feldspar extracts to test the bleaching behaviour for different transmission wavelength.

Recent advances in instrumentation and measurement protocols have played a key role in enabling the dating of fluvial sediments. OSL dating of quartz has been significantly improved by single-aliquot regenerative (SAR) protocols (Murray \& Wintle 2000; Wallinga et al. 2001). Sensitivity changes are monitored and corrected in the SAR protocol. This procedure allows the determination of equivalent dose by interpolation with a precision of up to $5 \%$.

Feldspar IRSL dating can be troubled by anomalous fading (WINTLE 1973) causing age underestimation. Anomalous fading is an athermal signal loss following irradiation and reflecting the instability of some of the electron traps. HunTLEY \& LAMOTHE (2001) pointed out that it is essential to determine the fading rate precisely and carried out fading experiments to correct the measured IRSL age estimates. However, age correction is problematic and a reliable procedure is still under discussion (AuCLAIR et al. 2003; LAMOTHE et al. 2003; HuOT \& LAмотне 2003). There is a close relation between fading rate and geological provenance. HunTLEY \& LAMOTHE (2001) determined fading rates for North American sediments ranging from 2 to $10 \%$ per decade (decade means a factor of 10 in time since irradiation). These fading corrections are restricted to the lowdose linear portion of the dose response and are not expected to be applicable to samples

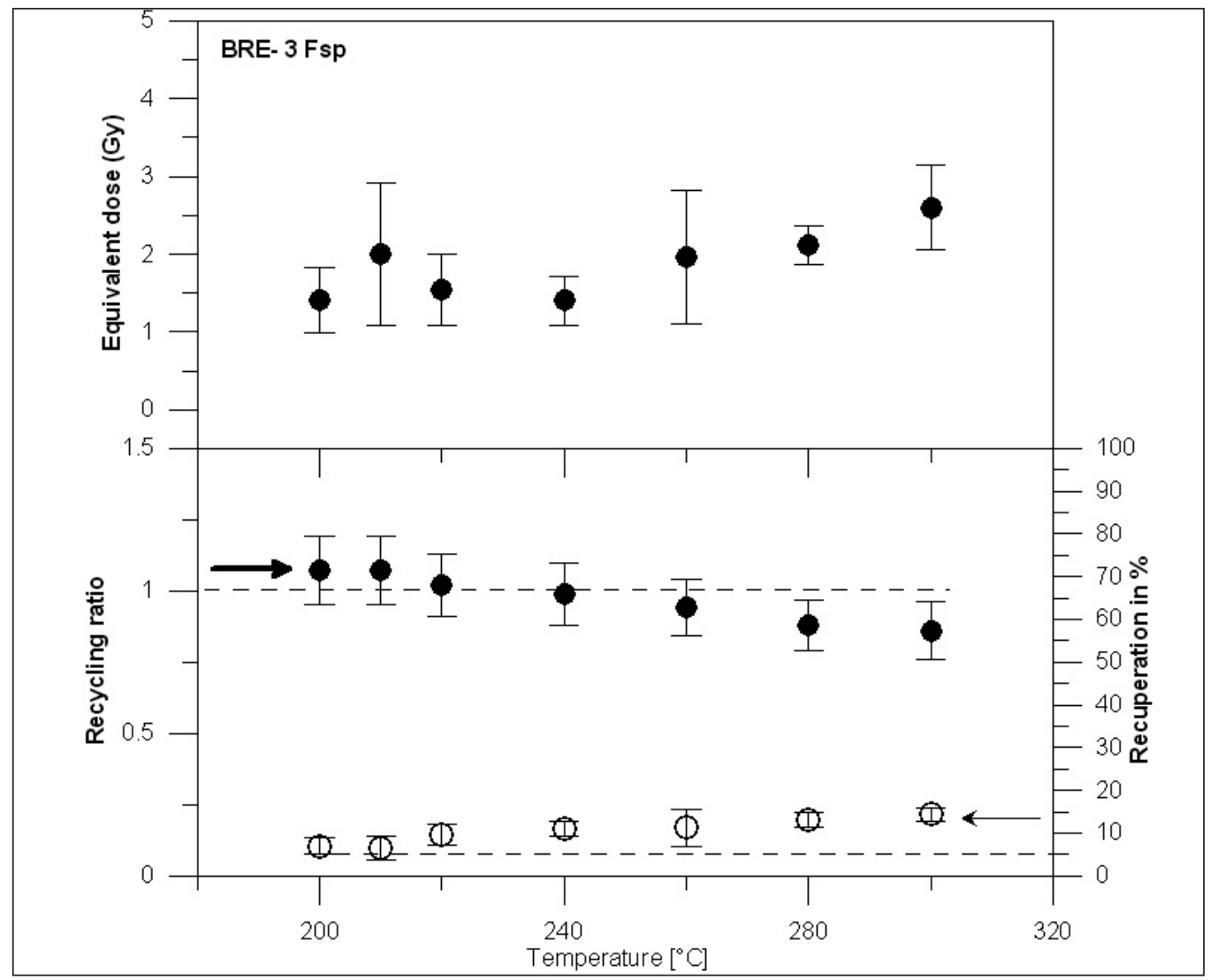

Fig. 6: Preheat plateau, recycling ratio and recuperation for sample BRE3 using feldspar extracts.

Abb. 6: „Preheat plateau”, „Recycling Ratio” und „Recuperation” für Feldspäte der Probe BRE3. 
older than $\sim 20$ - 50 ka. Fading corrections with a potential to be applicable over a much wider range are under discussion (LAмотHE et al. 2003). Parts of the time-dependent signal from feldspars using pulsed stimulation show less fading than others (Тsuкамото et al. 2006) and thus possibly providing another way of dating potassium-rich feldspars. PREUSSER et al. (2007) reported that long-term fading has apparently no effect on potassium-rich feldspar specimens from the Swiss Alpine Foreland.

Natural ionising radiation includes alpha, beta and gamma irradiation released by the radioactive decay of the unstable isotopes of the ${ }^{238} \mathrm{U},{ }^{235} \mathrm{U}$ and ${ }^{232} \mathrm{Th}$ decay chains, ${ }^{40} \mathrm{~K}$ and to a minor content ${ }^{87} \mathrm{Rb}$ and cosmic radiation. The dose rate depends on a number of external factors, some of them are even variable during burial time, like moisture, sediment thickness, grain-size, geochemical weathering of minerals or salts, mobilisation of clay minerals and radioactive equilibria/disequilibria of the decay chains and internal factors like the amount of ${ }^{40} \mathrm{~K}$ in potassium-rich feldspars.

\section{Experimental details and luminescence characteristics}

Four luminescence samples were taken in light-tight metallic cylinders from sand lenses intercalated in gravel-rich fluvial deposits. The outer light-exposed part of the sediment was removed under subdued light at both ends of the cylinder. The sample preparation included sieving to separate the $100-200 \mu \mathrm{m}$ or the $150-200 \mu \mathrm{m}$ grain-size fractions, followed by

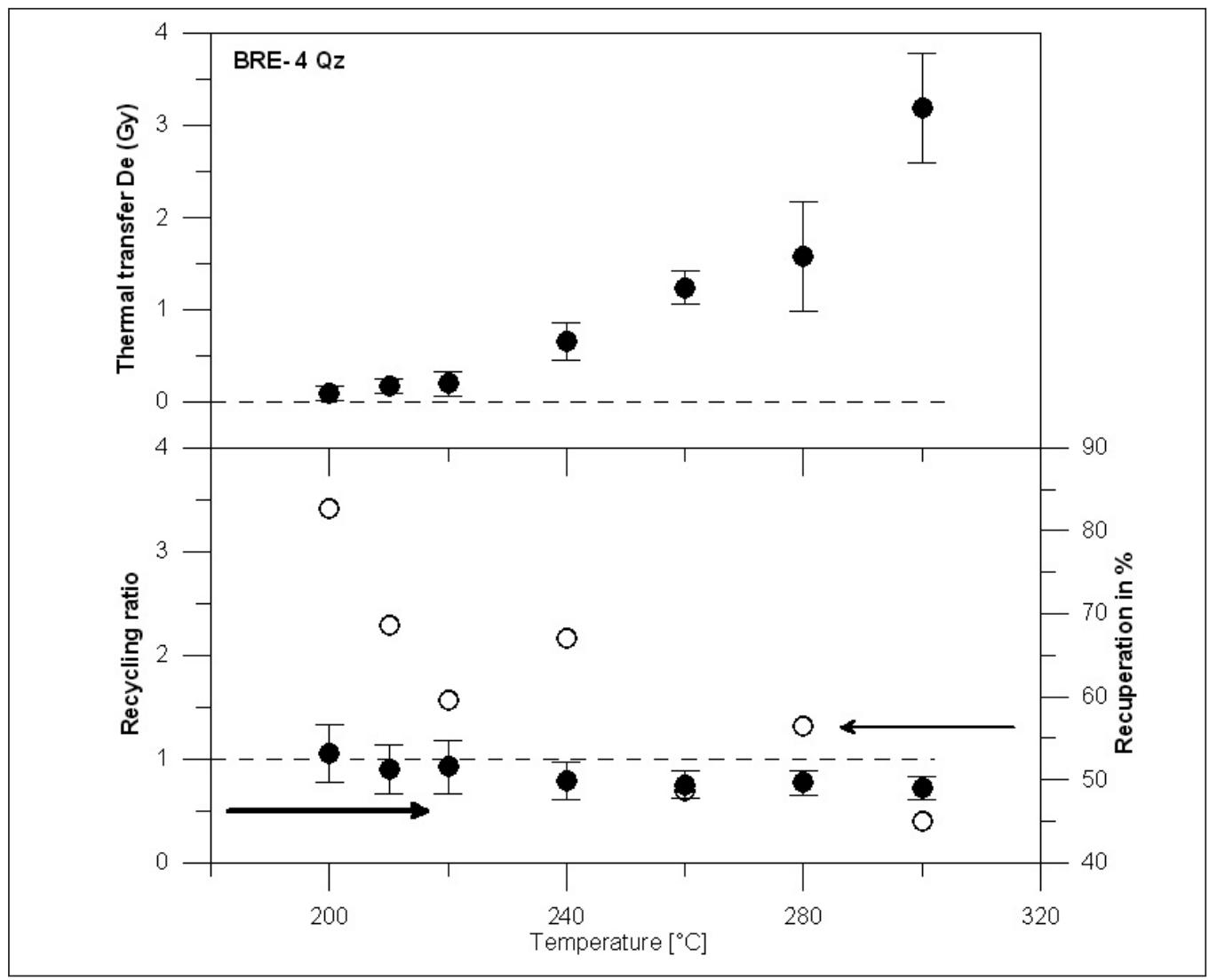

Fig. 7: Preheat plateau, recycling ratio and recuperation for sample BRE4 using quartz extracts.

Abb. 7: Preheat plateau”, „Recycling Ratio” und „Recuperation” für Quarze der Probe BRE4. 
removing the carbonates in $0,1 \mathrm{~N}$ hydrochloric acid, organic matter by $30 \%$ hydrogen peroxide and clay particles by sodium oxalate. The sandsized feldspar grains with densities lower than $2.58 \mathrm{~g} / \mathrm{cm}^{3}$ were extracted using heavy liquids and the sand-sized quartz was extracted from the remaining fraction using heavy liquids of 2.62 $\mathrm{g} / \mathrm{cm}^{3}$ and $2.70 \mathrm{~g} / \mathrm{cm}^{3}$ densities. The quartz extracts were etched with $40 \%$ hydrofluoric acid for 60 minutes to remove feldspars and sieved again with a $100 \mu \mathrm{m}$ mesh or $150 \mu \mathrm{m}$ mesh. The sand-sized quartz or feldspar grains were brought onto $0,9 \mathrm{~mm}$ steel discs (aliquots). IR stimulation was applied at the end of the quartz SAR protocol to test whether single aliquots show a contamination with feldspar deriving from inclusions after etching with hydrofluoric acid. Single aliquot regenerative-dose protocols were carried out for monomineralic quartz and feldspar extracts to determine the De values more precisely (MURRAY \& WinTLE 2000; WALLINGA et al. 2000, 2001). All growth curves were fitted using a saturating exponential function.

A number of tests were carried out on both quartz and feldspar extracts to investigate the luminescence characteristics and to evaluate the suitability of the applied SAR protocol for the samples under study.

\section{Preheat plateau}

To determine appropriate preheat conditions for the determination of De values and to avoid thermal transfer effects, the variation of equivalent dose with preheat temperature was measured for both feldspar and quartz

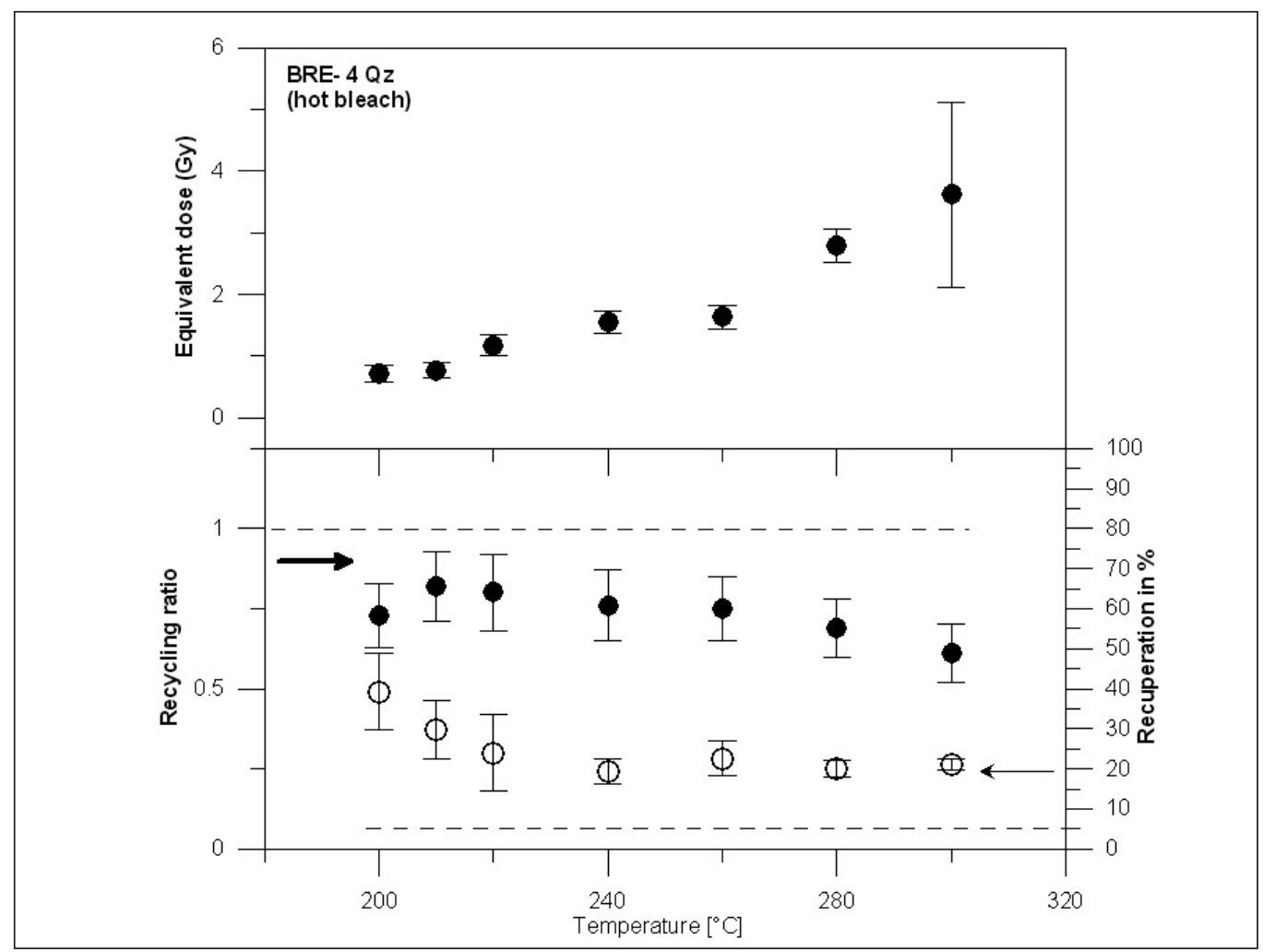

Fig. 8: Preheat plateau, recycling ratio and recuperation for sample BRE4 using quartz extracts. The hot bleach procedure was applied (MURRAY \& WinTLE 2003).

Abb. 8: „Preheat plateau“, „Recycling Ratio“ und „Recuperation“ für Quarze der Probe BRE4 unter Anwendung des „Hot Bleach“-Verfahrens (MurRay \& WintLe 2003). 
extracts. A plateau of $\mathrm{D}_{\mathrm{e}}$ values against preheat temperature for quartz and feldspar was determined using 10 seconds (s) preheats at $20^{\circ} \mathrm{C}$ intervals from 200 to $300^{\circ} \mathrm{C}$ (cp. Murray et al. 1997). Results were obtained from all samples. Examples of preheat plateau are given in Figs. 5-11. A preheat temperature of $210^{\circ} \mathrm{C}$ or $220^{\circ} \mathrm{C}$ for 10 seconds was used for natural and regenerative doses for quartz extracts and feldspar extracts.

\section{Recycling ratio}

Changes in the measured luminescence intensity with dose are known to occur in quartz and feldspar during single aliquot measurement procedures. Therefore a small test dose is given to each aliquot after the measurement of the natural or regenerated signal to determine sensitivity changes. The sensitivity correction is calculated by dividing the natural or regenerated IRSL or OSL intensity (Lx) by the test dose IRSL or OSL intensity (Tx). The recycling ratio $(\mathrm{Rx} / \mathrm{R} 1)$ is a test for the effectiveness of the sensitivity correction and determined by repeating the first dose point in the growth curve at the end of the measured cycle. The recycling ratio should be consistent with unity. Murray \& WintLe (2000) suggested that aliquots should be rejected if recycling ratios are outside $10 \%$ of unity. However, Murray \& WintLe (2000) pointed out that the recycling ratio only tests whether sensitivity changes following laboratory measurements have been accurately corrected for. Figures 5-11 show plots of recycling ratios for samples BRE1-4 show-

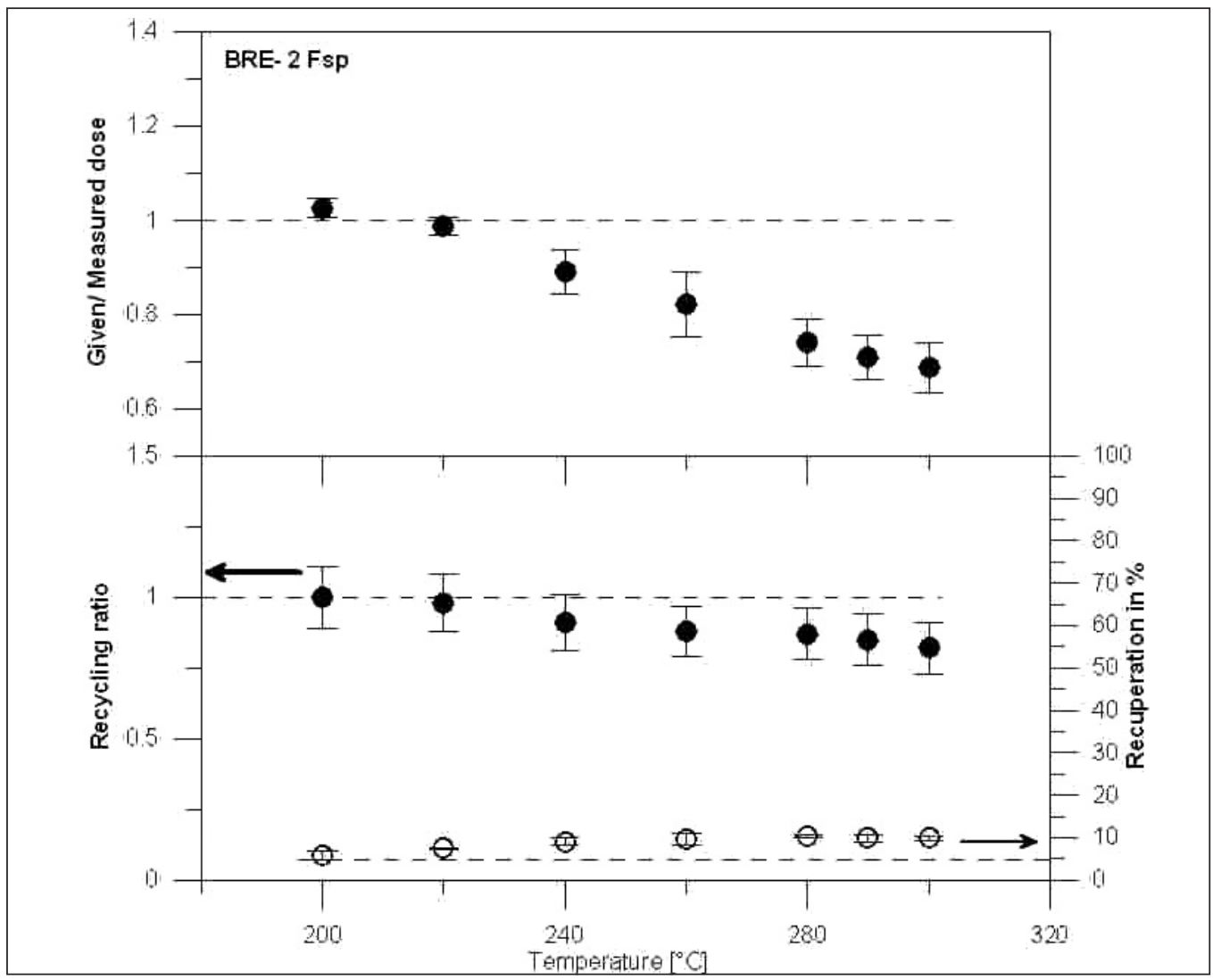

Fig. 9: Dose recovery test, recycling ratio and recuperation for sample BRE2 using feldspar extracts.

Abb. 9: „Dose recovery test“, „Recycling Ratio“ und „Recuperation“ für Feldspäte der Probe BRE2. 
ing that for most of the samples the aliquots fall within $10 \%$ of unity for the temperature range $200^{\circ}$ to $220^{\circ} \mathrm{C}$ indicating that the SAR sensitivity correction is appropriate for these samples. Furthermore, a hot bleach treatment was used for the quartz extracts. After measurement of the response to the test dose, the aliquots were exposed to the blue diodes for 40 seconds whilst holding them at $280^{\circ} \mathrm{C}$ in order to reduce any build up of slow components in the OSL signal (Murray \& Wintle, 2003). However, the recycling ratios concerning the hot bleach procedure for samples BRE3-quartz and BRE4-quartz fall only within $35 \%$ of unity indicating that the sensitivity correction is problematic although the final OSL age estimates are within 1-standard deviation in agreement with independent age control. The SAR proto- col for feldspar yielded recycling ratios within $10 \%$ of unity for the preheat temperature range between $200^{\circ}$ and $240^{\circ} \mathrm{C}$.

\section{Dose recovery test}

A successful dose recovery test indicates that the SAR protocol produces internally consistent results for a sample and evaluates the creditability of the equivalent dose measured from a natural sample and so confirms that the applied SAR protocol enables to recover a known laboratory dose (RHODEs 2000). After bleaching the aliquots with a dr. hönle solar simulator, the aliquots were given a known laboratory dose close to the De value. The artificially dosed aliquots were then treated as "natural" in the SAR protocol (Table 1) to determine the De value (here:

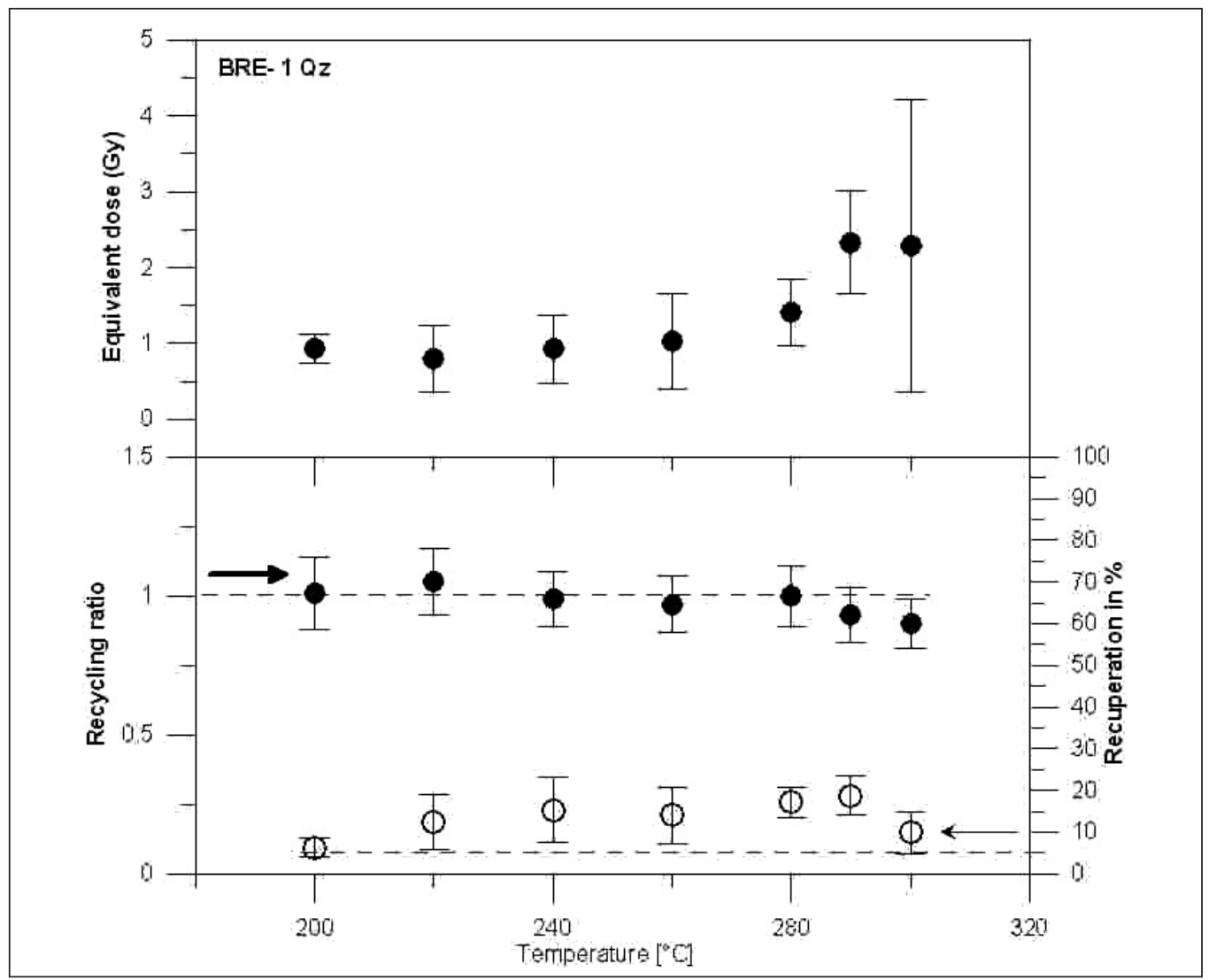

Fig. 10: Preheat plateau, recycling ratio and recuperation for sample BRE1 using quartz extracts.

Abb. 10: „Preheat plateau“, „Recycling Ratio“ und „Recuperation“ für Quarze der Probe BRE1. 
dose recovery). An example for dose recovery is given for sample BRE2-feldspar using a test dose of 1.0 Gy (Fig. 9). The dose recovery tests yielded the recovering dose values within $5 \%$ from the given dose in the preheat temperature range $200^{\circ}-220^{\circ} \mathrm{C}$.

An example for thermal transfer is given in Figure 7. Sample BRE4-quartz seems to be stable for the temperature range between $200^{\circ}$ and $220^{\circ} \mathrm{C}$ but shows an increasing amount of thermal transfer above $220^{\circ} \mathrm{C}$. Recuperation is insufficient over the whole temperature range for sample BRE4-quartz (Fig. 8), whereas recuperation is less than $10 \%$ and even less than $5 \%$ over the temperature range between $200^{\circ}$ and $240^{\circ} \mathrm{C}$ for sample BRE2-feldspar and BRE1-quartz (Fig. 9, 10). The hot bleach procedure gives a recuperation of $>20 \%$ over the temperature range from $200^{\circ}$ to $300^{\circ} \mathrm{C}$ for sample BRE4-quartz.

\section{Single-aliquot regenerative dose protocol}

The single-aliquot regenerative (SAR) dose protocol was applied to determine the De values for feldspar and quartz (MurRay \& WintLE 2000; Wallinga et al. 2000, 2001; Wintle \& Murray 2000). A dose response curve with typically three dose points is measured on a single aliquot by repeated irradiations, preheats and IRSL/OSL measurements. Sensitivity changes occurring due to laboratory heat treatment are monitored after each OSL measurement and corrected (Table 1). The weighted mean De value and the standard deviation were calculated for most of the samples

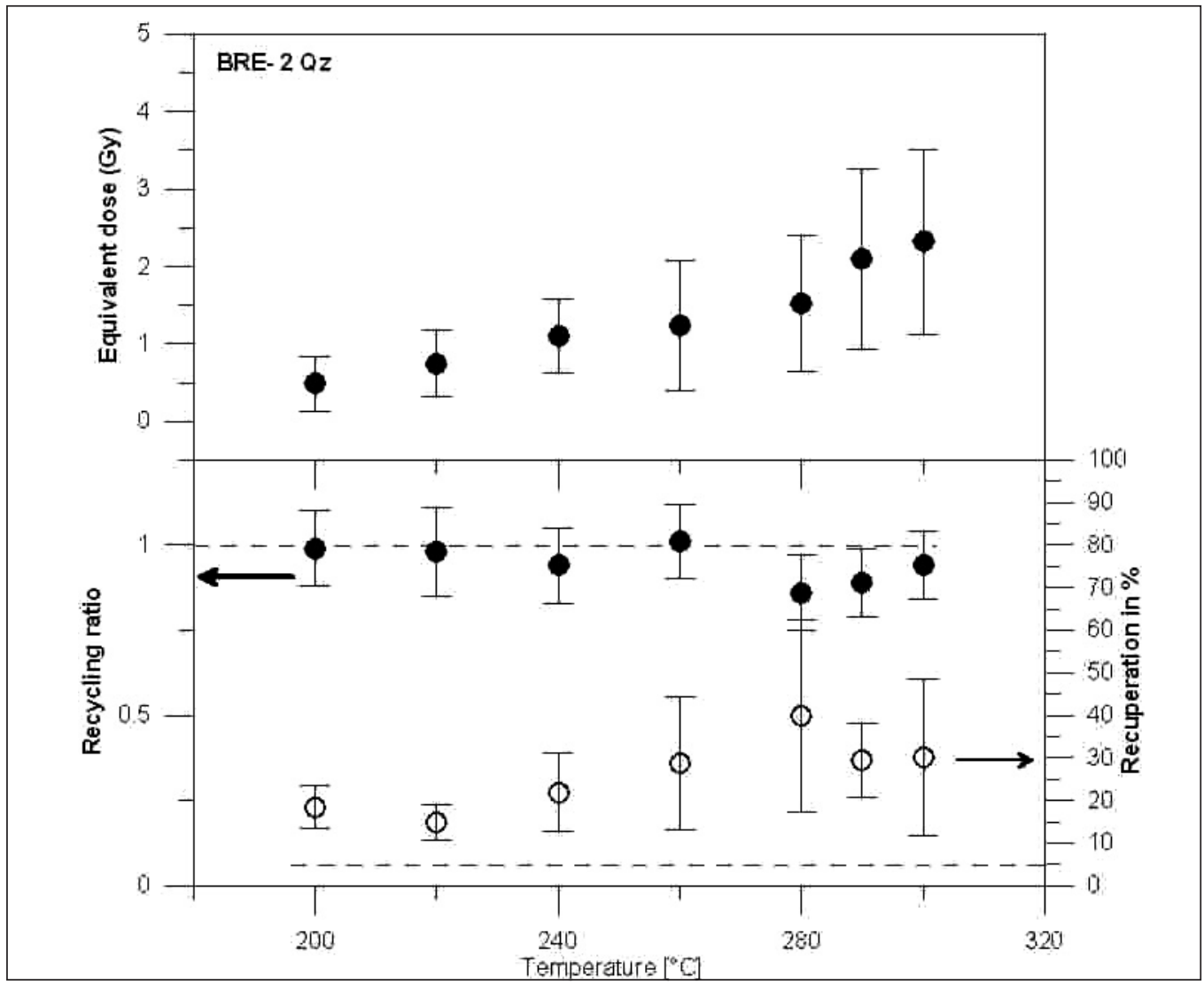

Fig. 11: Preheat plateau, recycling ratio and recuperation for sample BRE2 using quartz extracts.

Abb. 11: „Preheat plateau“, „Recycling Ratio“ und „Recuperation“ für Quarze der Probe BRE2. 
from 24 aliquots for both feldspar and quartz grains. In general, aliquots were taken into account within a 3-sigma standard deviation and a recycling ratio between 0.8 and 1.2. Most of the dose points for the natural signal plotted between first and second artificial dose step. The hot bleach procedure resulted in two outliers (samples BRE3 and BRE4) with recycling ratios of 0.87 . The IRSL signal was measured with a Schott BG39/Corning 7-59 filter combination between photomultiplier and feldspar extracts. A Schott U-340 filter with a detection window of 290-370 nm was placed for OSL measurements between photomultiplier and quartz extracts. Blue light emitting diodes were used for quartz stimulation.

Table 1: Single Aliquot Regenerative (SAR) protocol, as applied for quartz (Qz) (OSL stimulation) and feldspar (Fsp) grains (IRSL stimulation) (after MuRRAY \& WinTLE 2000; WaLlinga et al. 2000, 2001).

Tab. 1. SAR-Protokoll für Quarz (Qz) (OSL-Stimulation) - und Feldspatminerale (Fsp) (IRSL Stimulation) (nach Murray \& Wintle 2000; Wallinga et al. 2000, 2001).

1. Preheat of Natural

2. IRSL decay of naturals for $300 \mathrm{~s}$ at $50^{\circ} \mathrm{C} /$ OSL decay for 40 s at $125^{\circ} \mathrm{C}$

3. Test dose (10s)

4. Preheat of test dose of $210^{\circ} \mathrm{C}$ for $10 \mathrm{~s}$ (Fsp), and $210^{\circ} \mathrm{C}$ for $0 \mathrm{~s}(\mathrm{Qz})$

5. Measurement of test dose (IRSL decay for 300 s at $50^{\circ} \mathrm{C}$ for Fsp / OSL decay for 40 s at $125^{\circ} \mathrm{C}$ for $\mathrm{Qz}$ )

6. Regenerative dose

7. Preheat of regenerative dose for $10 \mathrm{~s}$ at $290^{\circ} \mathrm{C}$ (Fsp), $240^{\circ} \mathrm{C}$ or $260^{\circ} \mathrm{C}$ (Qz)

8. IRSL decay of regenerative dose for $300 \mathrm{~s}$ at $50^{\circ} \mathrm{C} / \mathrm{OSL}$ decay for $40 \mathrm{~s}$ at $125^{\circ} \mathrm{C}$

9. Test dose for $10 \mathrm{~s}$

10. Preheat of test dose at $210^{\circ} \mathrm{C}$ for $10 \mathrm{~s}$ (Fsp), and $160^{\circ} \mathrm{C}$ or $210^{\circ} \mathrm{C}$ for $0 \mathrm{~s}(\mathrm{Qz})$

11. IRSL decay for $300 \mathrm{~s}$ at $50^{\circ} \mathrm{C} / \mathrm{OSL}$ decay for $40 \mathrm{~s}$ at $125^{\circ} \mathrm{C}$

12. Repeat step 6-11 for R2, R3, zero point and recycling point

etc.
Equivalent dose determination was carried out using the software Analyst 6.0 (G.A.T. Duller, Aberystwyth, unpublished). Age calculation was applied by the software ADELE (M. Krbetschek, Freiburg, unpublished).

\section{Dosimetry}

As the outer shell of the feldspar minerals was not etched by hydrofluoric acid, alpha efficiency was estimated to a mean value of $0.2 \pm 0.1$ for all feldspar samples (Duller 1994). Dose rates for all samples were calculated from potassium, uranium and thorium contents, as measured by gamma spectrometry in the laboratory, assuming radioactive equilibrium for the decay chains. The following radioisotopes were measured: ${ }^{234} \mathrm{Th},{ }^{214} \mathrm{Bi},{ }^{214} \mathrm{~Pb}$ and ${ }^{212} \mathrm{~Pb}$ for uranium; ${ }^{228} \mathrm{Ac}$, ${ }^{208} \mathrm{Tl}$ and ${ }^{212} \mathrm{~Pb}$ for thorium and ${ }^{40} \mathrm{~K}$ for potassium. An average internal potassium content of $12 \pm 0.5 \%$ was applied for all feldspar samples (Huntley \& BARril 1997). Cosmic dose rate was corrected for the altitude and sediment thickness, as described by PrescotT \& HutTON (1994). The natural moisture content of the sediment was estimated between $10 \pm 2$ weight $\%$ and $15 \pm 5$ weight $\%$ for the samples.

\section{Results}

Dosimetric results, De values, IRSL and OSL age estimates are shown in Tables 2 and 3. Uncertainties are given in 1-sigma confidence interval. The total dose rates range from $2.21 \pm 0.22$ to $2.53 \pm 0.11 \mathrm{~Gy} / \mathrm{ka}$ and $1.60 \pm 0.05$ to $1.70 \pm 0.06$ $\mathrm{Gy} / \mathrm{ka}$ for feldspar and quartz, respectively. The $\mathrm{D}_{\mathrm{e}}$ values range from 0.6 to $1.1 \mathrm{~Gy}$ for quartz grains and from 1.6 to 2.0 Gray for feldspar extracts (Table 3), as determined by the SAR protocol (Table 1). Examples for the quartz and feldspar De-distributions of the single aliquot equivalent dose estimates and the radial plots of the same values are shown in figs. 12-15. They give an impression on the complete resetting of the OSL- signal prior to deposition. The radial plot (Fig. 15) displays an expanded De- distribution for the feldspar sample BRE4 indicating an insufficient bleaching of these minerals. In 
Table 2: Dosimetric results, as determined by gammaspectrometry (ppm=parts per million; $\mathrm{H}_{2} \mathrm{O}=$ moisture of sediment in weight \%).

Tab. 2: Dosimetrische Ergebnisse durch Gammaspektrometrie bestimmt ( $\mathrm{ppm}=$ part per million; $\mathrm{H}_{2} \mathrm{O}=$ moisture of sediment in weight \%).

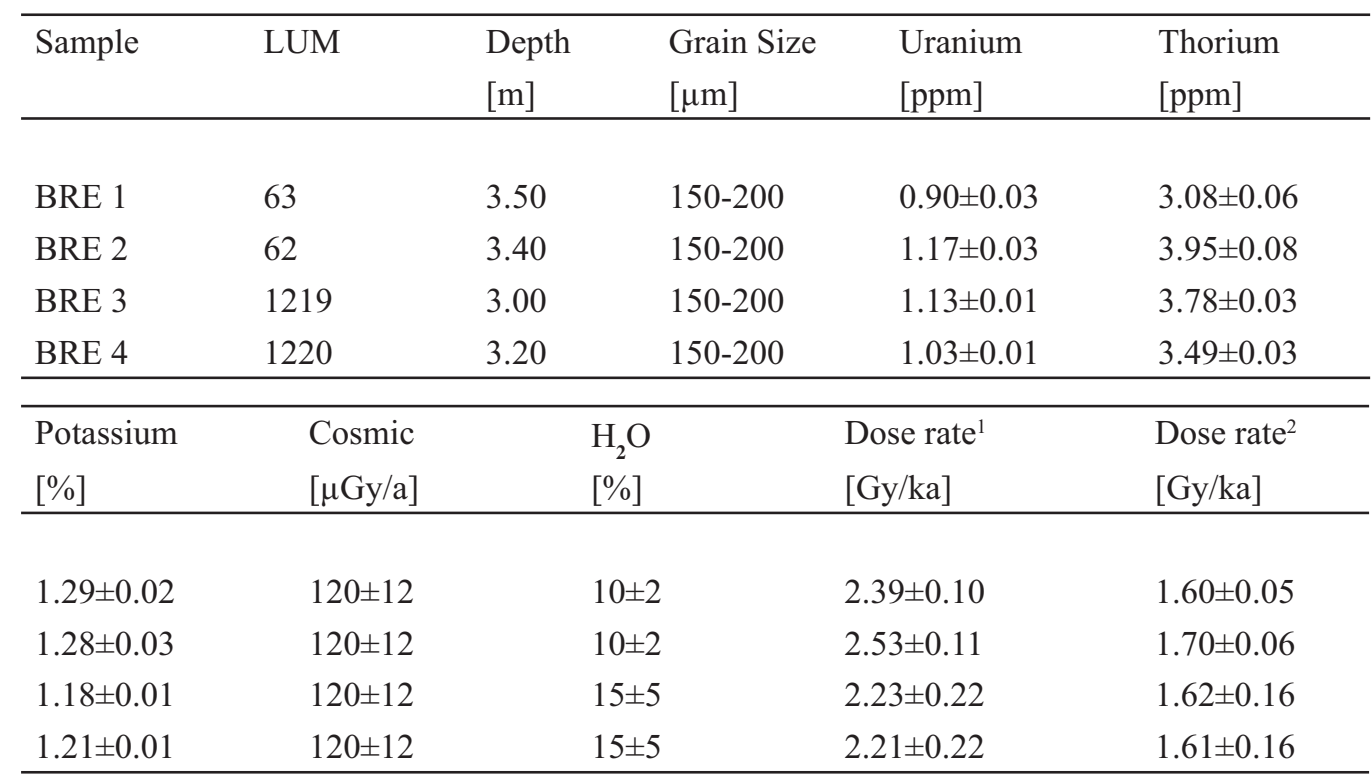

contrast the quartz (Fig. 12) of BRE4 (Fig. 14) shows a nearly typical Gaussian distribution indicating that the mean equivalent dose is an appropriate estimate for the burial dose. OSL age estimates are used for chronostratigraphic interpretation only. IRSL age estimates are used for methodological comparison in this study only. Two samples (BRE1 and BRE2) were taken from a sand lens at a depth of $3.40 \mathrm{~m}$ and 3.50 $\mathrm{m}$ below surface at the Bremgarten section in 2003. The IRSL age estimates gave $0.9 \pm 0.1$ $\mathrm{ka}$ and $1.0 \pm 0.1 \mathrm{ka}$, whereas OSL age estimates yielded $1.9 \pm 0.2 \mathrm{ka}$ and $1.4 \pm 0.1 \mathrm{ka}$. It is likely that the OSL age estimates for the two samples from Bremgarten are overestimated owing to the chosen preheat temperature of $260^{\circ} \mathrm{C}$ causing thermal transfer. Further experiments were unfortunately not possible owing to the lack of material. The samples BRE3 and BRE4 were taken in 2006 at the eastern wall of the gravel pit.

Sample BRE3 taken above a trunk, which was dated by radiocarbon, gave an OSL age estimate of $460 \pm 170$ a, whereas the IRSL age estimate on feldspar extracts yielded $740 \pm 270$ a.
The hot bleach procedure yielded an OSL age estimate of $370 \pm 130$ a, slightly age underestimated if compared with the radiocarbon ages on wood from the same profile. Age underestimation is also indicated by the dose recovery test. Sample BRE4 taken from below the trunk (Fig. 2) yielded OSL age estimates of $690 \pm 160$ a and $600 \pm 190$ a (hot bleach), which are in agreement within 1-sigma standard deviation with the results from sample BRE3. The IRSL age estimate is $890 \pm 60$ a.

A trunk of an oak tree was sampled from the fluvial deposits at a depth of $3.00 \mathrm{~m}$ below surface from the Bremgarten section and studied by radiocarbon dating. The sand most likely correlates to the top of the second fining-up cycle, whereas the trunk postdates the deposition of the second fining-up cycle. The wood is intercalated between the sand layers of samples BRE1 and BRE2. The wood gave a conventional radiocarbon age of $510 \pm 45 \mathrm{BP}$ (Hv 25350) resulting in a calibrated age of AD 1330-1440 (Table 4). The chronological results are stratigraphically consistent and in agree- 
ment with geological estimates. Two samples from a second trunk of the eastern wall taken in the same stratigraphic position and intercalating the sand layers of samples BRE3 and BRE4 gave radiocarbon ages of $440 \pm 45 \mathrm{BP}$ and $485 \pm 45$ BP resulting in calibrated radiocarbon ages of AD 1420-1480 and AD 1405-1445, respectively. The latter trunk from the eastern wall has about 40 tree-rings. Little variation in the thickness of the annual tree rings made the trunk unsuitable for dendrochronology (H.H. Leuschner, pers. com. 10/03/2008).

\section{Discussion and Conclusion}

In this study, we are confident that most of the quartz extracts yielded reliable results and uncertainties for $\mathrm{D}_{\mathrm{e}}$ values. The resulting OSL age estimates are in excellent agreement with the radiocarbon ages indicating that in large fluvial systems the mineral grains are sufficiently zeroed prior to final deposition owing to several cycles of remobilisation. Furthermore, the results show that OSL methods are suitable for dating fluvial deposits. It is important to note that age overestimation owing to insufficient bleaching prior to deposition does not seem to be dramatic for the sediments under study. But OSL dating is not precise enough to set up an annual or decadal resolution for fluvial sediment records owing to the error between 5 and $10 \%$ and the possibility of insufficient bleaching. IRSL dating yielded very likely age overestimation for the fluvial sands from the Bremgarten section, if compared with radiocarbon data and OSL dating results. Radiocarbon ages and IRSL age estimates are in agreement within 1-sigma standard deviation. From a stratigraphical point of view, the IRSL dating results are also reasonable and could give the true deposition age. However, fading correction was not applied for these feldspar extracts. A similar behaviour was described for samples from historically deposited sediments from the Rhine-Meuse system in the Netherlands (Wallinga et al. 2001; Erkens et al. 2009). The likely reason for this age overestimation is insufficient bleaching prior to deposition. However, the results are in stratigraphic order and small offsets for the youngest samples indicate that insufficient bleaching does not seem to be dramatic for the samples from Bremgarten. It is still under discussion whether changes in sensitivity during the measurement of the natural signal or contamination of the quartz fast component OSL signal by a less stable slow component are responsible for the IRSL age overestimation alternatively OSL age underestimation. It remains risky to extrapolate the results of Holocene fluvial sediments to those fluvially transported and deposited during the Weichselian glaciation.

Heterogenous radiation fields including an unequal distribution of radioisotopes in the sedi-

Table 3: Equivalent dose $\left(\mathrm{D}_{\mathrm{e}}\right)$ values in Gray (Gy) and luminescence age estimates in 1000 years (ka) for quartz and feldspar extracts using SAR protocols.

Tab. 3: Äquivalentdosis (De) in Gray (Gy) und Lumineszenz-Alter in 1000 Jahren (ka) für Quarz- und Feldspatextrakte mit einem SAR-Protokoll gemessen.

\begin{tabular}{lllllc}
\hline Sample & LUM & \multicolumn{2}{c}{ De value in [Gy] } & \multicolumn{2}{c}{ OSL Age in [ka] } \\
& & SAR-Fsp & SAR-Qz & SAR-Fsp & SAR-Qz \\
\hline & & & & & \\
BRE1 & 62 & $2.1 \pm 0.1$ & $3.0 \pm 0.3$ & $0.88 \pm 0.06$ & $1.9 \pm 0.2$ \\
BRE2 & 63 & $2.4 \pm 0.1$ & $2.4 \pm 0.1$ & $0.95 \pm 0.06$ & $1.4 \pm 0.1$ \\
BRE3 & 1219 & $1.6 \pm 0.6$ & $0.75 \pm 0.27$ & $0.74 \pm 0.27$ & $0.46 \pm 0.17$ \\
Hot bleach & 1219 & & $0.59 \pm 0.21$ & & $0.37 \pm 0.13$ \\
BRE4 & 1220 & $2.0 \pm 0.5$ & $1.10 \pm 0.26$ & $0.89 \pm 0.06$ & $0.68 \pm 0.16$ \\
Hot bleach & 1220 & & $0.97 \pm 0.26$ & & $0.60 \pm 0.19$ \\
\hline
\end{tabular}


Table 4: Radiocarbon data.

Tab. 4: Radiokohlenstoff-Daten.

\begin{tabular}{|l|l|l|c|c|l|l|}
\hline Hv & Sample & Material & Depth & $\delta^{13} \mathrm{C}$ & ${ }^{14} \mathrm{C}$ Age & calibrated time interval \\
\hline & & & $\mathrm{m}$ & $\% \mathrm{o}$ & Years BP. & cal ... \\
\hline 25350 & BRE 1 & Holz & - & -26.5 & $510 \pm 45$ & AD 1330 - 1440 \\
\hline 25637 & BRE 2 & Holz & - & -24.9 & $440 \pm 45$ & AD 1420-1480 \\
\hline 25638 & BRE 3 & Holz & - & -25.3 & $485 \pm 45$ & AD 1405-1445 \\
\hline
\end{tabular}

ment and the occurrence of insufficient bleaching prior to deposition can cause problems for the determination of De values, if small aliquots or single-grain techniques are applied (MAyya et al. 2006). Titanite, monazite and zircon are uranium- and thorium-rich minerals resulting in radioactive hot spots in the sedi- ments and thus giving reason for heterogenous microdosimetry, as previously described by using spatially resolved detection of luminescence (GREILICH \& WAGNER 2006).

At about 2800 cal BP during the transition from Subboreal to Subatlantic, climate abruptly changed from a relatively warm and continental

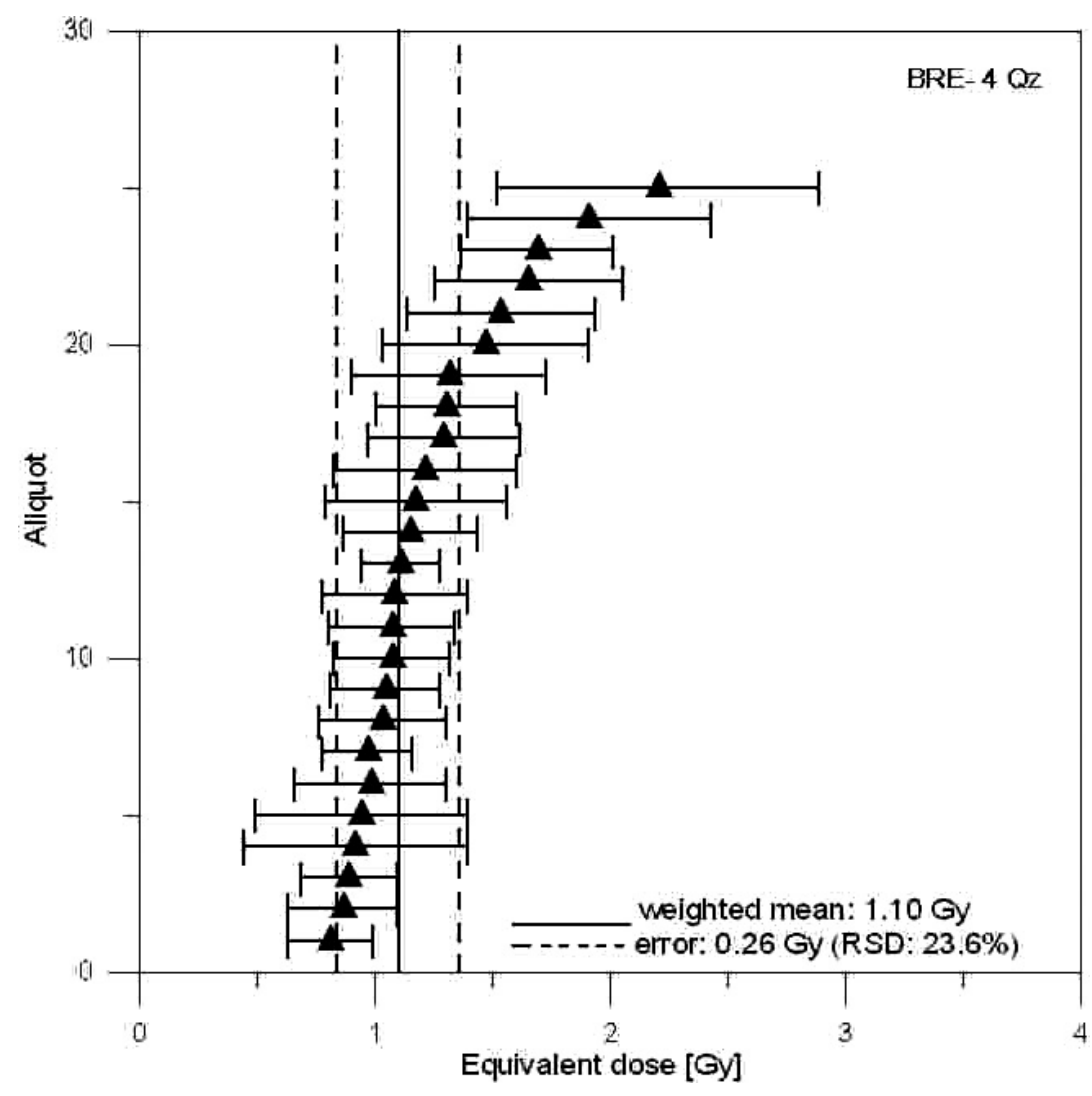

Fig. 12: Distribution of De values in increased order for quartz extracts of sample BRE4.

Abb. 12: Verteilung der De-Werte von Probe BRE4 (Quarz) in ansteigender Richtung angeordnet. 


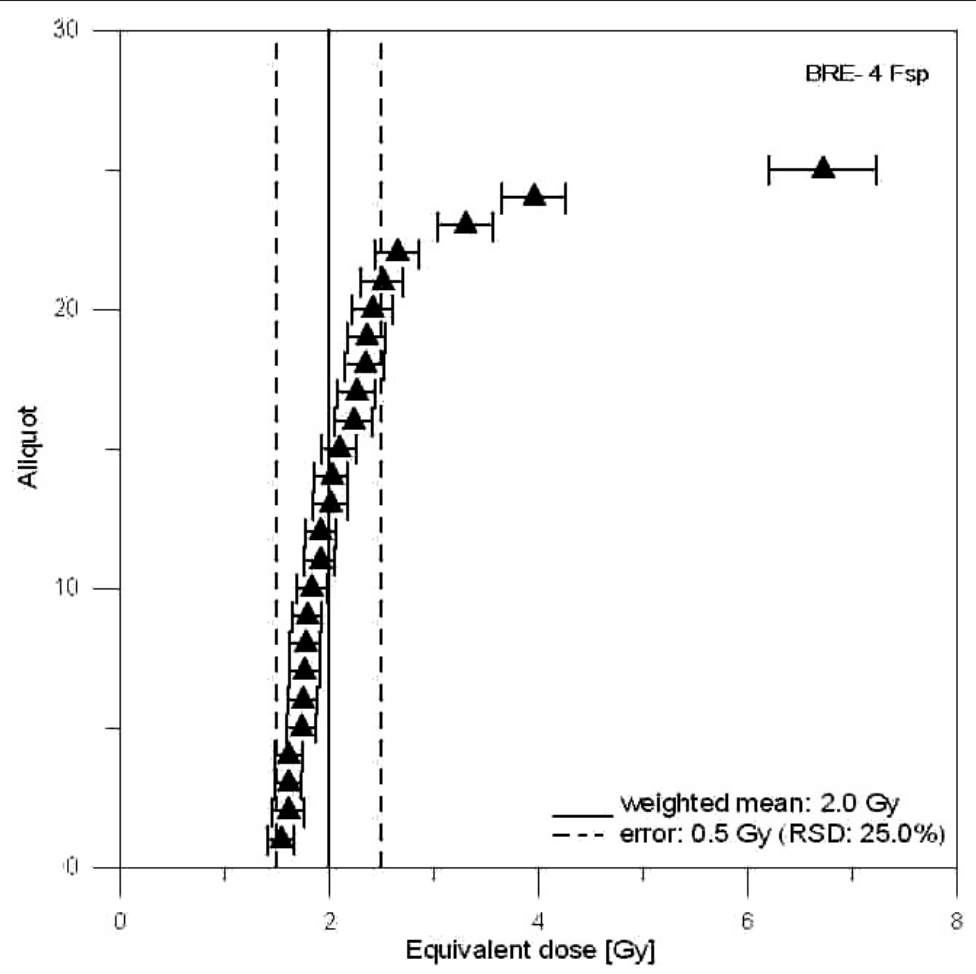

Fig. 13: Distribution of De values in increased order for feldspar extracts of sample BRE4.

Abb. 13: Verteilung der De-Werte von Probe BRE4 (Feldspat) in ansteigender Richtung angeordnet.

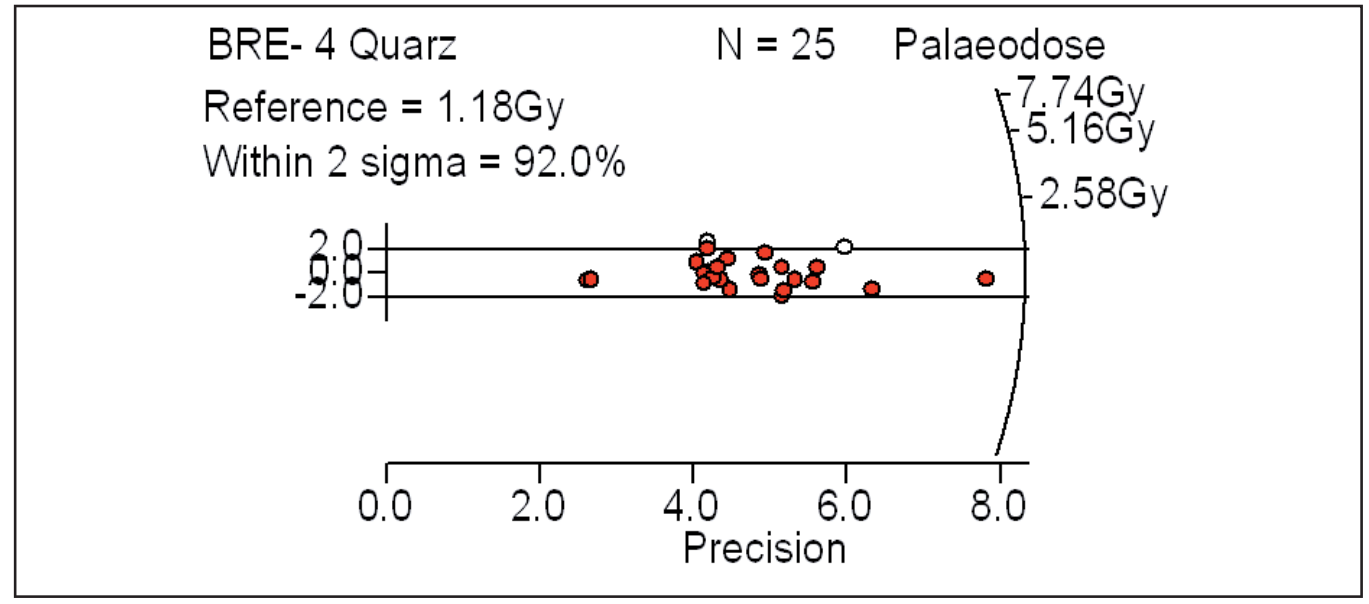

Fig. 14: Radial plot of De values for quartz extracts of sample BRE4. $92 \%$ of the data points are within the 2-sigma standard deviation.

Abb. 14: Radialplot der De-Werte von Probe BRE4 (Quarz). $92 \%$ der Datenpunkte liegen innerhalb der 2sigma Standardabweichung. 
climate to cooler and wetter conditions. The wetter climate in combination with intense human activity caused enhanced deforestation resulting in an increased erosion and run-off. Large amounts of waterlogged sediment were transported into the River Rhine causing a change in the meandering pattern of the river (Bos et al. 2008). Luminescence and radiocarbon dating results give evidence for a short period of major erosion and re-sedimentation of fluvial sediments from the "Tiefgestade" at the Bremgarten section between 500 and 600 years before present. This time period correlates with the beginning of the Little Ice Age lasting from about AD 1450 to 1850 (Bork 1989). Several severe floods occurred between 1500 and 1750, all correlated to the Little Ice Age; e.g. destruction of the village of Neuenburg AD 1525 (Glaser 2001). Furthermore, an extreme weather event resulting in a millenium flood is described for the year $\mathrm{AD}$ 1342. This flood caused a significant alteration of landscape such as up to $15 \mathrm{~m}$ deep incised canyons and reworking of 6-8 $\mathrm{m}$ thick fluvial sediments as debris flows in southern Germany (BORK 1989). The weather anomaly of AD 1342 could be very likely the reason for the fluvial dynamics including the aggradation of fluvial sediments more than $3 \mathrm{~m}$ thick in the southern
URG. The latest radiocarbon data make a correlation of this major sediment mobilisation with the weather anomaly of AD 1342 unlikely.

Based on the radiocarbon data, the serious historical earthquake around the city of Basel in the year AD 1356 seems to be also unlikely to have triggered such a flood causing erosion and accumulation of about $3.50 \mathrm{~m}$ of gravel at the Bremgarten section. However, the OSL age estimates do not clearly exclude a deposition age around the weather anomaly of AD 1342 or the Basel earthquake in the year AD 1356 owing to the large error.

In the Netherlands, the youngest drift sands from the Maas River yielded a radiocarbon age of $<1000 \mathrm{BP}$ and an OSL age estimate of $0.6 \pm 0.1$ ka (Bateman \& van Huissteden 1999) and so might be correlated with the remobilised fluvial sediments from the southern URG.

The present data set leaves us uncomfortably with questions about the linkage of the aggradation periods with climate forcing of the Rhine system in southern Germany. The results contradict the cold climate origin of terrace sediments in the southern Upper Rhine Graben and open up new challenging questions. Methodological problems, such as the degree of bleaching during fluvial transport are still

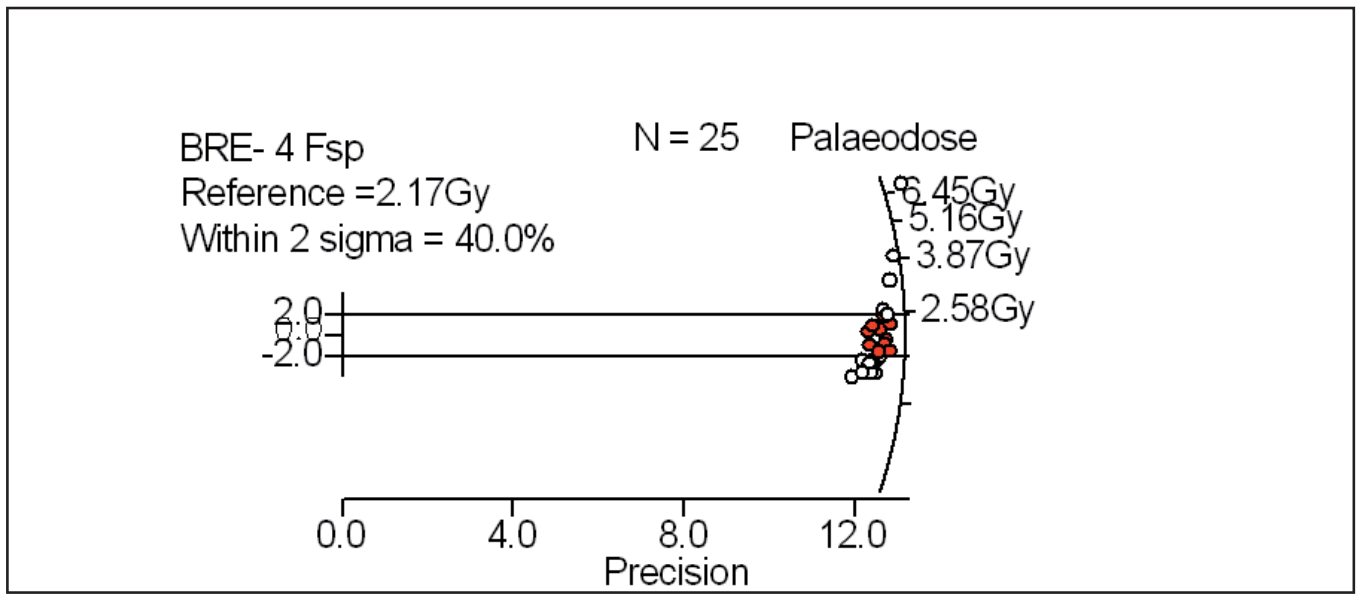

Fig. 15: Radial plot of De values for feldspar extracts of sample BRE4. $40 \%$ of the data points are within the 2-sigma standard deviation.

Abb. 15: Radialplot der De-Werte von Probe BRE4 (Feldspat). $40 \%$ der Datenpunkte liegen innerhalb der 2-sigma Standardabweichung. 
difficult to determine, although age overestimation in large river systems seems to be not as dramatical as previously described. The quartz SAR protocol is very likely the best method to apply OSL dating to fluvial deposits. However, the IRSL age estimates, although not fading corrected, are also in agreement within the 1-sigma standard deviation, if compared to radiocarbon dates and so give also likely true deposition ages. This is part of an ongoing study investigating the timing of periods of increased aggradation in the Rhine system highlighting the response of a Central European large river system situated in a tectonically active region to environmental and climate change.

\section{Acknowledgment}

This study was funded by the Deutsche Forschungsgemeinschaft (DFG) (HI 643/2-3), which is appreciated. We thank Dr. Frank Preusser and an anonymous referee for valuable improvements of a previous version of the manuscript. Sabine Mogwitz, Petra Posimowski and Sonja Riemenschneider are thanked for their excellent technical support and last but not least Juliane Herrmann for the art-work. Part of this study was done in the frame of a Bachelor thesis by Daniel Rimkus (FU Berlin).

\section{References}

Aitken, M.J. (1998): Introduction to Optical Dating. - 267 p.; Oxford (Oxford University Press).

Auclair, M., Lamothe, M. \& Нuot, S. (2003): Measurement of anomalous fading for feldspar IRSL using SAR. - Radiation Measurements, 37: 487-492.

BAILEy, R.M. \& ARnold, L.J. (2006): Statistical modelling of single grain quartz De distributions and an assessment of procedures for estimating burial dose. - Quaternary Science Reviews, 25: 2475-2502.

BARTZ, J. (1951): Revision des Bohrprofils der Heidelberger Radium-Sol-Therme. - Jahresbericht und wissenschaftliche Mitteilungen des Oberrheinischen Geologischen Vereins, N.F., 33: 101-125.

BARTZ, J. (1967): Recent movements in the Upper Rheingraben, between Rastatt and Mannheim.
- In: Rothe J.P. \& SAuER, K. (eds): The Rhinegraben Progress Report 1967. Abhandlungen Geologisches Landesamt Baden-Württemberg, 6: 1-2.

BARTZ, J. (1974): Die Mächtigkeit des Quartärs im Oberrheingraben. - In: Illies, J.H. \& Fuchs, K. (eds): Approaches to Taphrogenesis; - Inter-union Commission Geodynamics Scientific Report, 8: 78-87.

Bateman, M.D. \& Huissteden, K. van (1999): The timing of the last-glacial periglacial and aeolian events, Twente, eastern Netherlands. - Journal of Quaternary Science, 14: 277-283.

Boenigk, W. \& Frechen, M. (1998): Zur Geologie der Deckschichten von Kärlich/Mittelrhein. - Eiszeitalter und Gegenwart, 48: 38-49.

Boenigk, W. \& Frechen, M. (2006): The Pliocene and Quaternary fluvial archives of the Rhine system. - Quaternary Science Reviews, 25: 550-574.

BoRk, H.R. (1989): Soil erosion during the past millennium in central Europe and its significance within the geomorphodynamics of the Holocene. - Catena supplement, 15: 121-131.

Bos, J.A.A., Dambeck, R., Kalis, A.J., Schweizer, A. \& Thiemeyer, H. (2008): Palaeoenvironmental changes and vegetation history of the northern Upper Rhine Graben (southwestern Germany) since the Lateglacial. - Netherlands Journal of Geosciences - Geologie en Mijnbouw, 87/1: 67-90.

Bram, K., Wirsing, G., Brost, E., Elsass, P. \& Wonik, T. (2005): Kombinierte geophysikalische Erkundung der Aquifergeometrie und der Chloridverbreitung im quartären Grundwasserleiter des südlichen Oberrheingrabens zwischen Breisach und Fessenheim. - Berichte Naturforschende Gesellschaft Freiburg i. B., 95/1: 47-69.

Busschers, F. (2008): Unravelling the Rhine - Response of a fluvial system to climate change and sea-level oscillation. - PhD thesis, 183 p., Vrije Universiteit Amsterdam.

Duller, G.A.T. (1994): Luminescence dating of sediments using single aliquots: New procedures. - Quaternary Science Reviews, 13: 149-156.

Ellwanger, D., Gabriel, G., Hoselmann, C., Lämmermann-Barthel, J. \& Weidenfeller, M. (2005): The Heidelberg Drilling Project (Upper Rhine Graben, Germany). - Quaternaire, 16/3: 191-199.

Erkens, G., Dambeck, R., Volleberg, K.P., Bouman, M.T.I.J., Bos, J.A.A., Cohen, K.M., Wallinga, J. \& Hoek, W.Z. (2009): Fluvial terrace formation in the northern Upper Rhine Graben during the 
last 20000 years as a result of allogenic controls and autogenic evolution. - Geomorphology, doi: 10.1016/j.geomorph.2008.07.021.

FreChen, M. (1995): Lumineszenz-Datierungen der pleistozänen Tierfährten von Bottrop-Welheim. - Münchner Geowissenschaftliche Abhandlungen, 27: 63-80.

Frechen, M., Horváth, E. \& Gábris, G. (1997): Geochronology of Middle and Upper Pleistocene loess sections in Hungary. - Quaternary Research, 48: 291-312.

Frechen, M., Sierralta, M., Oezen, D. \& Urban, B. (2006): Uranium-series dating of peat from Central and Northern Europe. - In: SiRocko, F., Claussen, M., Sanchez-Goni, M.F. \& Litt, T. (eds.): The climate of past interglacials. - Quaternary Sciences, 7: 93-117.

Fuchs, M. \& Wagner, G.A. (2003): Recognition of insufficient bleaching by small aliquots of quartz for reconstructing soil erosion in Greece. - Quaternary Science Reviews, 22: 1161-1167.

Fuchs, M., Straub, J. \& Zöller, L. (2005): Residual luminescence signals of recent river flood sediments: a comparison between quartz and feldspar of fine- and coarse-grain sediments. -Ancient TL, 23: 25-30.

Glaser, R. (2001): Klimageschichte Mitteleuropas - 1000 Jahre Wetter, Klima und Katastrophen. - 227 p.; Darmstadt (Wissenschaftliche Buchgesellschaft).

Greilich, S. \& Wagner, G.A. (2006): Development of spatially resolved dating technique using HROSL. - Radiation Measurements, 41: 738-743.

Hagedorn, E.-M. \& Boenigk, W. (2008): The Pliocene and Quaternary sedimentary and fluvial history of the Upper Rhine Graben based on heavy mineral analyses. - Netherlands Journal of Geosciences - Geologie en Mijnbouw, 87: 21-32.

HindERER, M. (2001): Late Quaternary denudation of the Alps, valley and lake fillings and modern river loads. - Geodinamica Acta, 14: 231-263.

Huntley, D.J., Godfrey-Smith, D.I. \& Thewalt, M.L.W. (1985): Optical dating of sediments. - Nature, 313: 105-107.

Huntley, D.J. \& Barril, M.R. (1997): The K content of the K-feldspars being measured in optical dating or in thermoluminescence dating. - Ancient TL, 15: 11-13.

Huntley, D.J. \& Lamothe, M. (2001): Ubiquity of anomalous fading in K-feldspars and the measurement and correction for it in optical dating. - Canadian Journal of Earth Sciences, 38: 10931106.
Huot, S. \& Lamothe, M. (2003): Variability of infrared stimulated luminescence properties from fractured feldspar grains. - Radiation Measurements, 37: 499-503.

HÜtT, G., JaEK, I. \& Tchonka, Y. (1988): Optical dating: K-feldspars optical response stimulation spectra. - Quaternary Science Reviews, 7: 381-386.

Hütt, G. \& Jungner, H. (1992): Optical and TL dating on glaciofluvial sediments. - Quaternary Science Reviews, 11: 161-163.

HütTNER, R. (1991): Bau und Entwicklung des Oberrheingrabens - Ein Überblick mit historischer Rückschau. - Geologisches Jahrbuch, E48: 17-42.

Jain, M., Murray, A.S. \& Bötter-Jensen, L. (2003): Optically stimulated luminescence dating: How significant is incomplete bleaching in fluvial environments. - Quatenaire, 15: 143-157.

Lämmermann-Barthel, J., Hinderer, M., Neeb, I. \& Frechen, M. (accepted): Late glacial to Holocene fluvial aggradation and incision in the southern Upper Rhine Graben - climatic and tectonic controls. - Quatenaire.

Lamothe, M., Balescu, S., Auclair, M. (1994): Natural IRSL intensities and apparent luminescence ages of single feldspar grains extracted from partially bleached sediments. - Radiation Measurements, 23: 555-561.

Lamothe, M., Auclair, M., Hanazaoui, C. \& Huot, S. (2003): Towards a prediction of long-term anomalous fading of feldspar IRSL. - Radiation Measurements, 37: 493-498.

Lepper, K., Agersnap, N., Larsen, S. \& McKeever, S.W.S. (2000): Equivalent dose distribution analysis of Holocene aeolian and fluvial quartz sands from Central Oklahoma. - Radiation Measurements, 32: 603-608.

Lian, O.B. \& Roberts, R.G. (2006): Dating the Quaternary: progress in luminescence dating of sediments. - Quaternary Science Reviews, 25: 2449-2468.

Mayya, Y.S., Morthekai, P., Murarib, M.K. \& Singhvi, A.K. (2006): Towards quantifying beta microdosimetric effects in single-grain quartz dose distribution. - Radiation Measurements, 41: 1032-1039.

Murray, A.S., Olley, J.M. \& Caitcheon, G.G. (1995): Measurement of equivalent doses in quartz from contemporary water-lain sediments using optically stimulated luminescence. - Quaternary Science Reviews, 14: 365-371.

Murray, A.S. \& Roberts, R.G. (1997): Determining the burial time of single grains of quartz using 
optically stimulated luminescence. - Earth Planetary Science Letters, 152: 163-180.

Murray, A.S., Roberts, R.G. \& Wintle, A.G. (1997): Equivalent dose measurement using a single aliquot of quartz. - Radiation Measurements, 27: 171-184.

Murray, A.S. \& Wintle, A.G. (2000): Luminescence dating of quartz using an improved singlealiquot regenerative-dose protocol. - Radiation Measurements, 32: 57-73.

Murray, A.S. \& Wintle, A.G. (2003): The single aliquot regenerative dose protocol potential for improvements in reliability. - Radiation Measurements, 37: 377-381.

Nivière, B., Brüstle, A., Bertrand, G., Carretier, S., Behrmann, J. \& Gourry, J.C. (2008): Active tectonics of the southern Upper Rhine Graben, Freiburg area (Germany). - Quaternary Science Reviews, 27: 541-555.

Olley, J.M., Catcheon, G.G., Roberts, R.G. (1999): The origin of dose distributions in fluvial sediments, and the prospect of dating single grains from fluvial sediments using optically stimulated luminescence. - Radiation Measurements, 20: 207-217.

Prescott, J.R. \& Hutton, J.T. (1994): Cosmic ray contributions to dose rates for luminescence and ESR dating: large depths and long-term time variations. - Radiation Measurements, 23: 497-500.

Preusser, F., Blei, A., Graf, H. \& Schlüchter, C. (2007): Luminescence dating of Würmian (Weichselian) proglacial sediments from Switzerland: methodological aspects and stratigraphical conclusions. - Boreas, 36: 130-142.

Preusser, F., Degering, D., Fuchs, M., Hilgers, A., Kadereit, A., Klasen, N., Krbetschek, M., Richter, D. \& SPencer; J.Q.G. (2008): Luminescnce dating: basics, methods and applications. - Eiszeitalter und Gegenwart (Quaternary Science Journal), 57/1-2: 95-149.

RHODES, E.J. (2000): Observations of thermal transfer OSL signals in glacigenic quartz. - Radiation Measurements, 32: 595-602.

Rhodes, E.J. \&, Pownall, L. (1994): Zeroing of the OSL signal in quartz from young glaciofluvial sediments. - Nuclear Tracks and Radiation Measurements, 23: 581-585.

RitTentour, T.M. (2008): Luminescence dating of fluvial deposits: application to geomorphic, palaeoseismic and archaeological research. - Boreas, 37: 613-635.

Schirmer; W., Bos, J.A.A., Dambeck, D., Hinderer, M., Preston, N., Schulte, A., Schwalb, A. \&
Wessels, M. (2005): Holocene fluviatile processes and valley history in the River Rhine catchment. - In: Herget, J. \& DiKau, R. (eds.): Natural and Human Impacts in the River Rhine Catchment. - Erdkunde, 59: 199-215.

Singarayer, J.S., Bailey, R.M., Ward, S. \& Stokes, S. (2005): Assessing the completeness of optical resetting of quartz OSL in the natural environment. - Radiation Measurements, 40: 13-25.

Tsukamoto, S., Denby, P.M., Murray, A.S. \& BötTER-JENSEN, L. (2006): Time-resolved luminescence from feldspars: New insight into fading. - Radiation Measurements, 41: 790-795.

Wallinga, J. (2002): Optical dating of fluvial deposits: a review. - Boreas, 31: 302-323.

Wallinga, J., Murray, A.S. \& Wintle, A.G. (2000): The single-aliquot regenerative-dose (SAR) protocol applied to coarse-grain feldspar. - Radiation Measurements, 32: 529-533.

Wallinga, J., Duller, G.A.T., Murray, A.S. \& TÖRnQuist, T.E. (2001): Testing optically stimulated luminescence dating of sand-sized quartz and feldspar from fluvial deposits. - Earth and Planetary Science Letters, 193: 617-630.

Weidenfeller, M. \& Kärcher, T. (2008): Tectonic influence on fluvial preservation: aspects of the architecture of Middle and Late Pleistocene sediments in the northern Upper Rhine Graben, Germany. - Netherlands Journal of Geosciences - Geologie en Mijnbouw, 87: 33-40.

Westerhoff, W. (2008): Stratigraphy and sedimentary evolution. The lower Rhine-Meuse system during the Late Pliocene and Early Pleistocene (southern North Sea Basin). - PhD thesis, Vrije Universiteit Amsterdam: 1-168.

Wessels, M. (1998): Natural environmental change indicated by Late Glacial and Holocene sediments from Lake Constance, Germany. - Palaeoclimatology, Palaeogeography, Palaeoecology, 140: 421-430.

WintLe, A.G. (1973): Anomalous fading of thermoluminescence in mineral samples. - Nature, 245: 143-144.

WintLe, A.G. (1997): Luminescence dating: laboratory procedures and protocols. - Radiation Measurements, 27: 769-817.

WintLe, A.G. (2008): Luminescence dating: where it has been and where it is going. - Boreas, 37: 471-482.

WintLe, A.G. \& Murray, A.S. (2000): Quartz OSL: effects of thermal treatment and their relevance to laboratory dating procedures. - Radiation Measurements, 32: 387-400. 